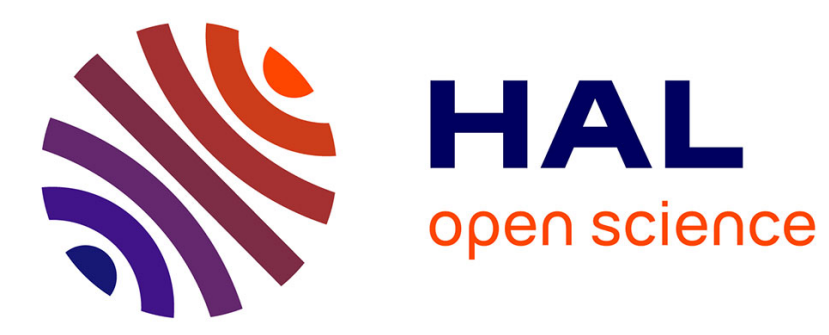

\title{
Geophysical constraints for terrane boundaries in southern Mongolia.
}

\author{
A Guy, Karel Schulmann, Marc Munschy, J.-M Miehe,, J.B. Edel, O Lexa, D \\ Fairhead.
}

\section{- To cite this version:}

A Guy, Karel Schulmann, Marc Munschy, J.-M Miehe,, J.B. Edel, et al.. Geophysical constraints for terrane boundaries in southern Mongolia.. Journal of Geophysical Research, 2014, 119, pp.7966-7991. 10.1002/2014jb011026 . hal-01216959

\section{HAL Id: hal-01216959 \\ https://hal.science/hal-01216959}

Submitted on 12 Oct 2021

HAL is a multi-disciplinary open access archive for the deposit and dissemination of scientific research documents, whether they are published or not. The documents may come from teaching and research institutions in France or abroad, or from public or private research centers.
L'archive ouverte pluridisciplinaire HAL, est destinée au dépôt et à la diffusion de documents scientifiques de niveau recherche, publiés ou non, émanant des établissements d'enseignement et de recherche français ou étrangers, des laboratoires publics ou privés. 


\section{Journal of Geophysical Research: Solid Earth}

\section{RESEARCH ARTICLE \\ 10.1002/2014JB011026 \\ Geophysical constraints for terrane boundaries in southern Mongolia}

Key Points:

- Terranes in southern Mongolia are compared with the potential field data

- No systematic correspondence

between the geophysical domains and the terranes

\section{Correspondence to:}

A. Guy,

alexandra.guy@gmail.com

\section{Citation:}

Guy, A., K. Schulmann, M. Munschy, J.-M. Miehe, J.-B. Edel, O. Lexa, and D. Fairhead (2014), Geophysical constraints for terrane boundaries in southern Mongolia, J. Geophys. Res. Solid Earth, 119, 7966-7991, doi:10.1002/2014JB011026.

Received 6 FEB 2014 Accepted 2 OCT 2014 Accepted article online 7 OCT 2014 Published online 30 OCT 2014

\author{
Alexandra Guy ${ }^{1,2,3}$, Karel Schulmann ${ }^{1,3}$, Marc Munschy ${ }^{3}$, Jean-Marc Miehe ${ }^{2}$, Jean-Bernard Edel ${ }^{3}$, \\ Ondrej Lexa ${ }^{1,4}$, and Derek Fairhead ${ }^{5}$ \\ ${ }^{1}$ Centre for Lithospheric Research, Czech Geological Survey, Prague, Czech Republic, ${ }^{2}$ AREVA MINES, Paris, France, ${ }^{3}$ Institut \\ de Physique du Globe, Université de Strasbourg, Strasbourg, France, ${ }^{4}$ Institute of Petrology and Structural Geology, Faculty \\ of Science, Charles University, Prague, Czech Republic, ${ }^{5} \mathrm{GETECH}$, Leeds, UK
}

Abstract The Central Asian Orogenic Belt (CAOB) is a typical accretionary orogen divided into numerous lithostratigraphic terranes. In theory, these terranes should be characterized by contrasting magnetic and gravity signatures owing to their dissimilar petrophysical properties. To test this hypothesis, the extent of tectonostratigraphic terranes in southern Mongolia was compared with the potential field data. The analysis reveals that the terrane boundaries are not systematically defined by strong gravity and magnetic gradients. The correlation of the magnetic signal with the geology reveals that the magnetic highs coincide with Late Carboniferous to Early Permian volcanic-plutonic belts. The matched filtering shows a good continuity of signal along the boundaries of these high magnetic anomalies toward the deeper crustal levels which may indicate the presence of deeply rooted tectonomagmatic zones. The axes of high-density bodies in the western and central parts of the study area are characterized by periodic alternations of NW-SE trending gravity anomalies corresponding to up to $20 \mathrm{~km}$ wide cleavage fronts of Permo-Triassic age. The matched filtering analysis shows good continuity of signal to the depth of these gravity highs which may indicate presence of deeply rooted high-strain zones. The magnetic signal is interpreted to be as the result of a giant Permo-Triassic magmatic event associated with lithosphere-scale deformation, whereas the gravity pattern is related to the postaccretionary shortening of the $C A O B$ between the North China and Siberia cratons.

\section{Introduction}

Lithostratigraphical, geochronological, and structural studies [e.g., Zonenshain, 1973; Şengör et al., 1993; Badarch et al., 2002; Windley et al., 2007; Kröner et al., 2010] have shown that the Central Asian Orogenic Belt $(\mathrm{CAOB})$ is composed of contrasting lithotectonic domains. These terranes are described as lithospheric/crustal blocks bounded by strike-slip faults or sutures. Suture zones are commonly defined as crustal or lithospheric inhomogeneities characterized by deep-seated, steeply dipping high-strain zones containing ophiolitic fragments, blueschist mélanges, and occasionally eclogites. Dewey [1977] discussed the complexities of suture zones, drawing attention to the important distinction that should be made between them and other high-strain zones generated by folding, thrusting, and deformation along intracontinental convergent zones. In addition, in deeply eroded old orogens, the sutures may be difficult to identify because continuous convergence and successive reactivations may reduce the sutures to very narrow zones and obliterate the record of high-pressure metamorphism. Thus, the terrane concept in southern Mongolia is based on the existence of contrasting tectonostratigraphic units and their boundaries, interpreted as sutures, which are deduced from the abrupt juxtaposition of these units along steep strike-slip faults. Given that the typical criteria defining suture zones are poorly developed in southern Mongolia, the classical approach to the definition of terranes can lead to ambiguities [Şengör and Dewey, 1990], partly because of the lack of supporting geophysical data such as seismic profiles and potential field maps.

At the scale of orogens, suspect terranes exhibit contrasting magnetic and gravity signatures [Jones et al., 1983; Wellman, 1988; Banka et al., 2002; Glen et al., 2007a; Burton, 2010] because the gravity and magnetic signals depend on the petrophysical properties (density and magnetic susceptibility) of the constituent rocks. However, the primary difficulty associated with the interpretation of any gravity and magnetic data is to distinguish the contribution to the geophysical field from sources located at different depths. Techniques like spectral analysis [Spector and Grant, 1970; Syberg, 1972] have been applied to magnetic and gravity anomalies to estimate the contributions from shallow, intermediate, and deep sources in order to constrain 


\section{QAGU Journal of Geophysical Research: Solid Earth}

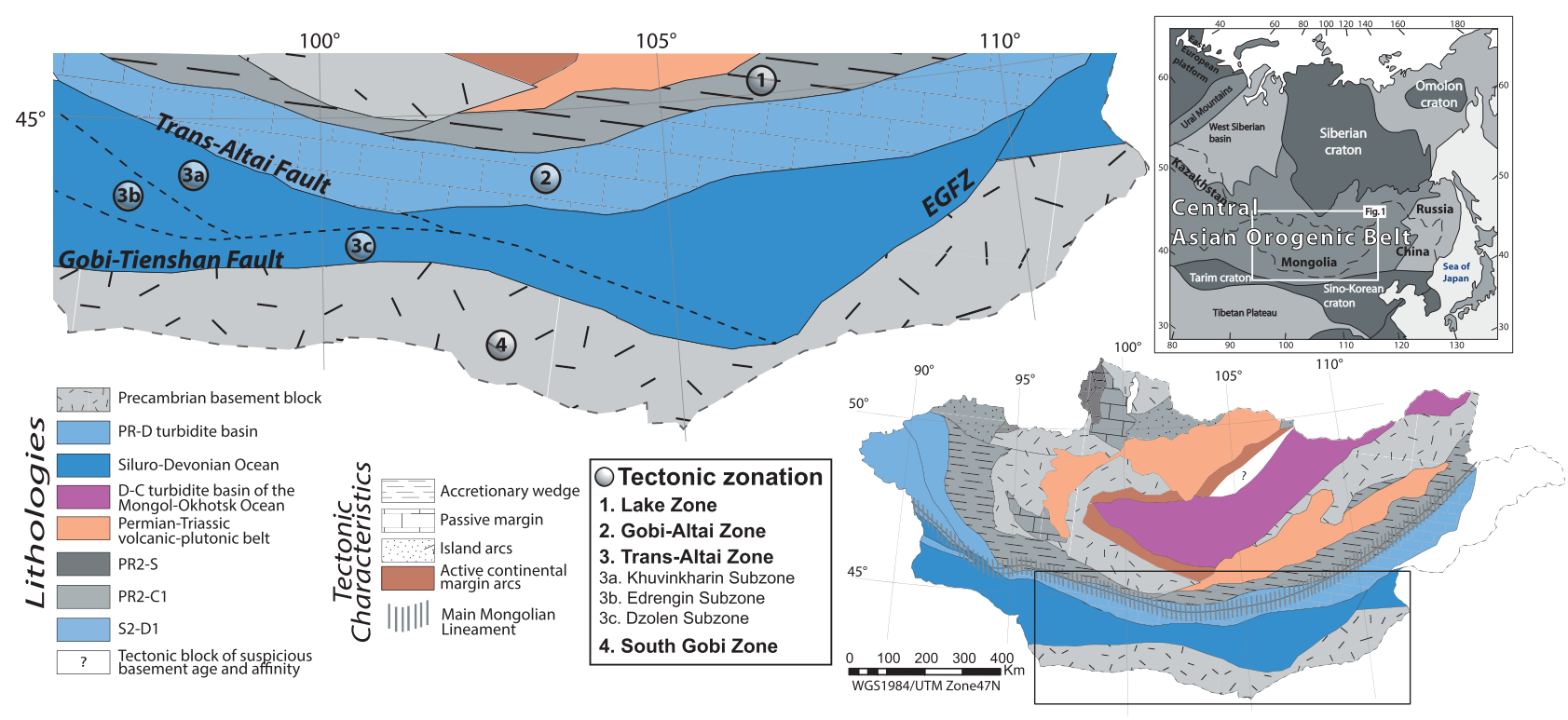

Figure 1. Lithotectonic map of southern Mongolia showing the distribution of the continental and oceanic domains, alternating with island arcs, cratons, and sutures (modified after Guy et al. [2014]). PR: Proterozoic; S: Silurian; D: Devonian; C: Carboniferous; P: Permian; T: Trias; J: Jurassic; and EGFZ: East Gobi Fault Zone. The black and white inset displays the tectonic regional context of Mongolia in Asia, and the colorful inset shows the lithotectonic units of the Central Asian Orogenic Belt in Mongolia. Black rectangle shows the studied area in southern Mongolia.

the structure of the crust. Therefore, especially in the absence of seismic profiles, the interpretation of gravity and magnetic data combined with lithostratigraphic analysis can be a powerful tool for testing the existence and distribution of suspect terranes in accretionary systems.

However, in the CAOB, which is considered to be a typical accretionary orogen [Şengör et al., 1993; Windley et al., 2007; Cawood et al., 2009], geophysical characterization of the terranes has not been carried out yet. To fill this gap, the available gravity and magnetic data for the southern part of the CAOB covering southern Mongolia have been compared here with the lithological, structural, and stratigraphic patterns mapped across this region so that both the surface and deep crustal architecture of the orogeny can be reviewed.

\section{Geological and Tectonic Setting}

Mongolia is located in the southern central part of the $C A O B$, a large accretionary orogen, which covers one third of the present continent of Asia. It is bordered by the Siberian craton to the north, the North China and Tarim cratons to the south, and the European platform to the west (Figure 1).

Badarch et al. [2002] synthesized the results of 60 years of geological mapping of Mongolia and developed a model of terranes providing a new and challenging view of the long-lasting accretionary history of the CAOB in central Asia. Forty-four separate terranes were identified and classified as cratonic, metamorphic, passive margin, island arc, fore arc/back arc, accretionary complex, and ophiolites. The differences in terminology and in the position of terrane boundaries led Kröner et al. [2010] to rationalize previous studies by introducing "tectonic zones." From north to south, the Lake Zone, the Gobi-Altai Zone, the Trans-Altai Zone, and the South Gobi Zone were defined (Figure 1). The geographical distribution of the E-W trending lithotectonic zones depicted in Figure 1 is a result of the combination of previous lithostratigraphic, structural, geochronological, and tectonic analyses [Şengör and Natal'in, 1996; Parfenov et al., 2001, 2003; Badarch et al., 2002; Xiao et al., 2004, 2008; Kuzmichev et al., 2005; Volkova and Sklyarov, 2007; Windley et al., 2007; Kröner et al., 2010].

The so-called Dzabkhan and Baydrag microcontinents [Didenko et al., 1994; Kozakov et al., 1997, 2002] consisting of Precambrian basement rocks unconformably overlain by Cambrian passive margin sequences lie north of the Lake Zone (Figure 1). The Lake Zone itself is a complex of Neoproterozoic volcanic arcs, and accretionary prisms thrust over the Baydrag and Dzabkhan basement rocks. The Cambrian age of emplacement of the Lake Zone accretionary system was dated by cooling ages of the eclogitic mélange and ophiolites [Štípská et al., 2010]. The Gobi-Altai Zone (Figure 1) consists of a thick Cambrian and Ordovician 
volcano-sedimentary sequence covered by a carbonate shelf of Silurian to Devonian age (back-arc basin of Badarch et al. [2002]) and a metamorphic core (metamorphic terrane) consisting of Devonian migmatites and granulites [Kozakov et al., 2002; Kröner et al., 2010; Lehmann et al., 2010]. The Gobi-Altai region was a proximal passive margin during the Early Devonian [Zonenshain, 1973; Zorin et al., 1993] as shown by characteristic platform sediments. The Trans-Altai Zone (Figure 1) consists of several lithotectonic units interpreted as Devonian volcanic arcs, back arcs, accretionary complexes, and ophiolites [Badarch et al., 2002]. In fact, the Trans-Altai Zone shows evidence of the exhumation of lithospheric mantle during the Silurian in areas corresponding to a distal passive margin environment [Ruzhentsev and Pospelov, 1992; Ruzhentsev, 2001]. It is therefore likely that the passive margin sequences in the Gobi-Altai and the exhumed mantle in the Trans-Altai reflect the progressive formation of an oceanic crust during the Early Devonian which corresponds to the opening of the so-called Palaeo-Asian Ocean [Zonenshain, 1973; Zorin et al., 1993; Lamb and Badarch, 2001]. The South Gobi Zone (Figure 1) consists of a Precambrian basement covered by Ordovician and Silurian siliciclastic sediments, Devonian volcano-sedimentary rocks, and Carboniferous volcanic rocks. In the model of Badarch et al. [2002], this tectonic zone is composed of passive margin, volcanic arc, and cratonic terranes.

Most authors agree that the Variscan accretion of the Mongolian CAOB took place during the Late Devonian and Early Carboniferous [e.g., Ruzhentsev and Pospelov, 1992; Ruzhentsev, 2001; Kröner et al., 2010] as shown by the emplacement of synconvergent Japan-type arcs in the Gobi-Altai Zone [Lehmann et al., 2010] and thrusting of the ophiolitic nappes in the Trans-Altai Zone [Zonenshain et al., 1975]. The whole system was refolded by Carboniferous N-S upright folds [Lehmann et al., 2010; Guy et al., 2014]. The South Gobi Zone is affected by subhorizontal greenschist facies shear zones and upright folding of Late Carboniferous age [Guy et al., 2014]. Both the Lake Zone and the Gobi-Altai Zone exhibit the characteristics of an active margin in which magmatism took place during the Late Carboniferous [Kozlovsky et al., 2012; Yarmolyuk et al., 2013], followed by the intrusion of alkaline plutons in the Permian, the event associated with the formation of grabens, bimodal volcanism, and partial melting of the crust [Yarmolyuk et al., 2008].

The review of geological units and terranes presented above shows that the geological subdivision of southern Mongolia into four major tectonic zones broadly reflects the Palaeozoic evolution of the region. At a large scale, the geology of southern Mongolia is characterized by two E-W trending continental blocks in the north and south and a major oceanic domain in the center. In order to avoid potential bias related to inconsistent terrane definitions, and to make the correlation between geological and potential fields anomaly possible, geological information from the area of interest has been reviewed and a new geological map produced at a scale of 1:500,000. This geological map (Figure 2) is a compilation of approximately 60 Russian and Mongolian 1:200,000 scale geological maps. The new map highlights the juxtaposition of E-W trending elongated massifs of Palaeozoic rocks exposed at ridges in between of young intermontane basins filled by Mesozoic and Cenozoic sediments [Cunningham et al., 2009]. The new geological map shows that lithological inventory of individual mountain ranges systematically differs in their proportions of Devonian volcanic and volcano-sedimentary rocks, Carboniferous clastics, and ophiolitic fragments. Based on this observation and in agreement with Zonenshain [1973], it is considered that the tectonic subdivision of southern Mongolia into four principal tectonic zones is more appropriate for the purposes of geological and geophysical correlation, even though the terrane boundaries of Badarch et al. [2002] are also shown in Figure 2.

\section{Geophysical Data and Processing}

\subsection{Potential Field Data}

In general, the magnetic field attenuates faster than the gravity field with distance from the source, the magnetic anomalies are better at revealing the features of the upper and middle crust, whereas the gravity field can be used to interpret deeper crustal structures.

\subsubsection{Magnetic Data}

Magnetic anomaly data were provided by Geophysical Exploration Technology (GETECH) in collaboration with the Mongolian Geological and Geophysical Exploration Company. These data have been digitized from maps of five airborne surveys of $1 \times 1 \mathrm{~km}$ spatial resolution. Due to the vector inclination of the measured magnetic field, the magnetic anomalies are asymmetric and are not centered over their sources except at the magnetic poles where the magnetic field is vertical. In order to remove the asymmetry of the magnetic anomalies and to center them over their sources, a reduction to the north magnetic pole has been applied to the data. 


\section{AGU. Journal of Geophysical Research: Solid Earth}

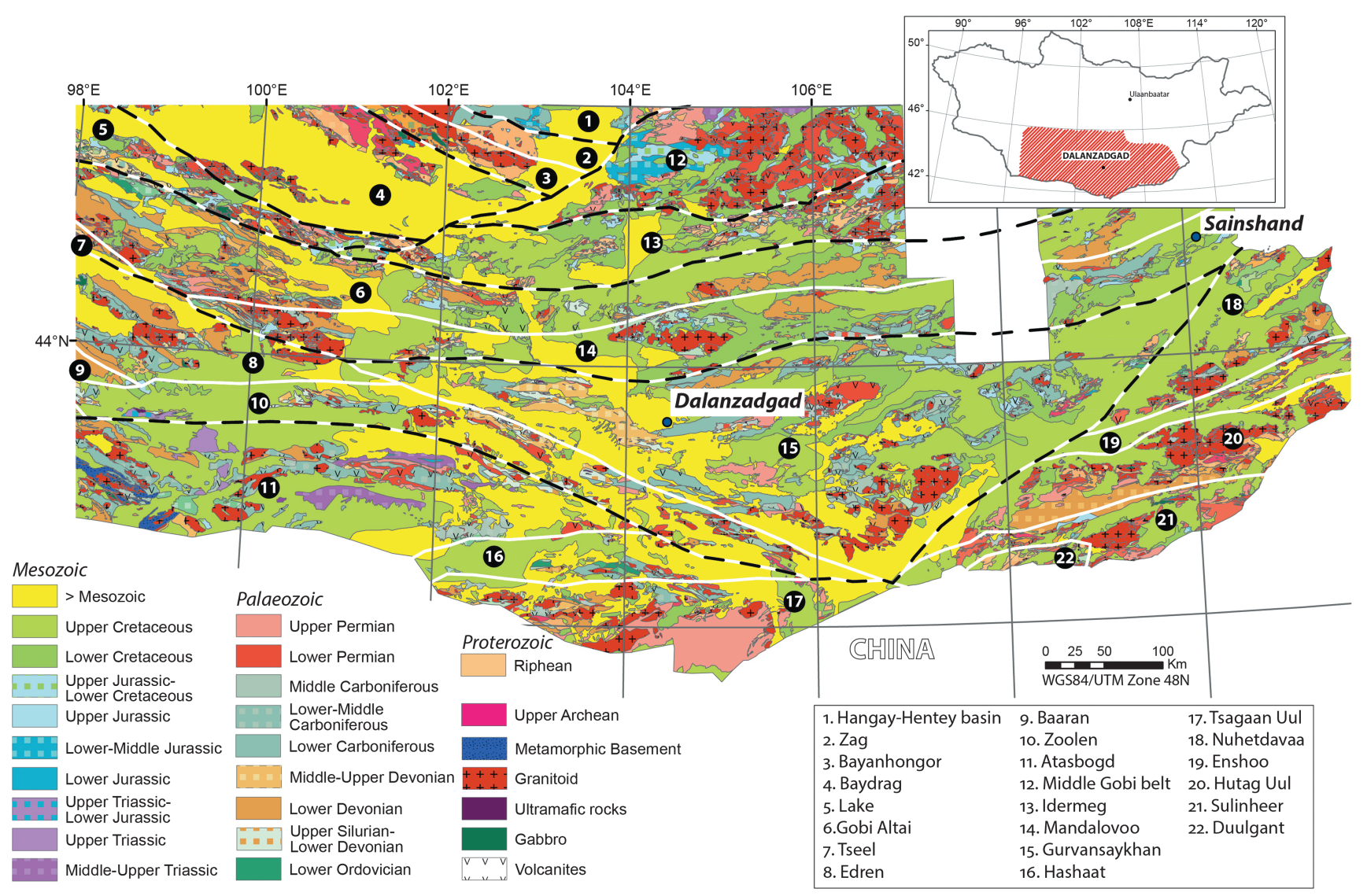

Figure 2. Geological map of 1:500,000 scale over the south of Mongolia (synthesis of at least 60 geological maps of 1:200,000) and its corresponding legend (color according to the International Chronostratigraphic Chart). The inset shows the location of the area covered by the geological map. The white lines are the terrane boundaries defined by Badarch et al. [2002] and the numbers referred to their attributed names. The dotted black lines are the tectonic boundaries defined in Figure 1.

As the data acquisition of the five surveys were spread over 1966 to 1990 (Table 1), the surveys have been separately reduced to the pole according to the International Geomagnetic Reference Field (IGRF) before being leveled and merged. The magnetic anomaly map obtained (Figure 3a) ranges from $-600 \mathrm{nT}$ to $800 \mathrm{nT}$.

\subsubsection{Gravity Data}

The gravity data used for the south of Mongolia are a free-air anomaly grid available at a spatial resolution of $2 \times 2 \mathrm{~min}$ from the DNSC08 free-air gravity model (Figure $3 \mathrm{~b}$ ). This model is a compilation by the Technical University of Denmark [Andersen and Knudsen, 2009] and covers the whole of Mongolia and its surroundings. The DNSC08 free-air gravity model values over land have been derived as part of the development of the EGM2008 model by Pavlis et al. [2012] at the National Geospatial-Intelligence Agency. However, over Mongolia, the 2 min grid combines high-resolution topographic information with airborne and terrestrial gravity data. Therefore, it should contain the essential wavelengths from all the airborne and terrestrial gravity surveys. Taking into account the number of sources from which the different gravity data sets used to

Table 1. International Geomagnetic Reference Fields Used to Reduce to the Pole Each Survey ${ }^{\mathrm{a}}$

\begin{tabular}{lccccc} 
Survey Areas & Year of the Survey & Corresponding IGRF & $F(\mathrm{nT})$ & $I$ (deg) & $D($ deg) \\
\hline Green contours & 1981 & 1980 & $58,009.8$ & 66.6 & -2.4 \\
Orange contours & $1989-1990$ & 1990 & $57,371.4$ & 64.7 & -0.7 \\
Purple contours & $1987-1988$ & 1990 & $57,683.5$ & 65.1 & -0.5 \\
Brown contours & 1967 & 1965 & $58,502.7$ & 62.5 & -4 \\
Blue contours & 1966 & 1965 & $60,853.2$ & 65 & -5.2 \\
\hline
\end{tabular}

${ }^{\mathrm{a}} \mathrm{F}$ : magnitude of the regional magnetic field; I: the inclination; and $D$ : the declination. 


\section{AGU. Journal of Geophysical Research: Solid Earth}

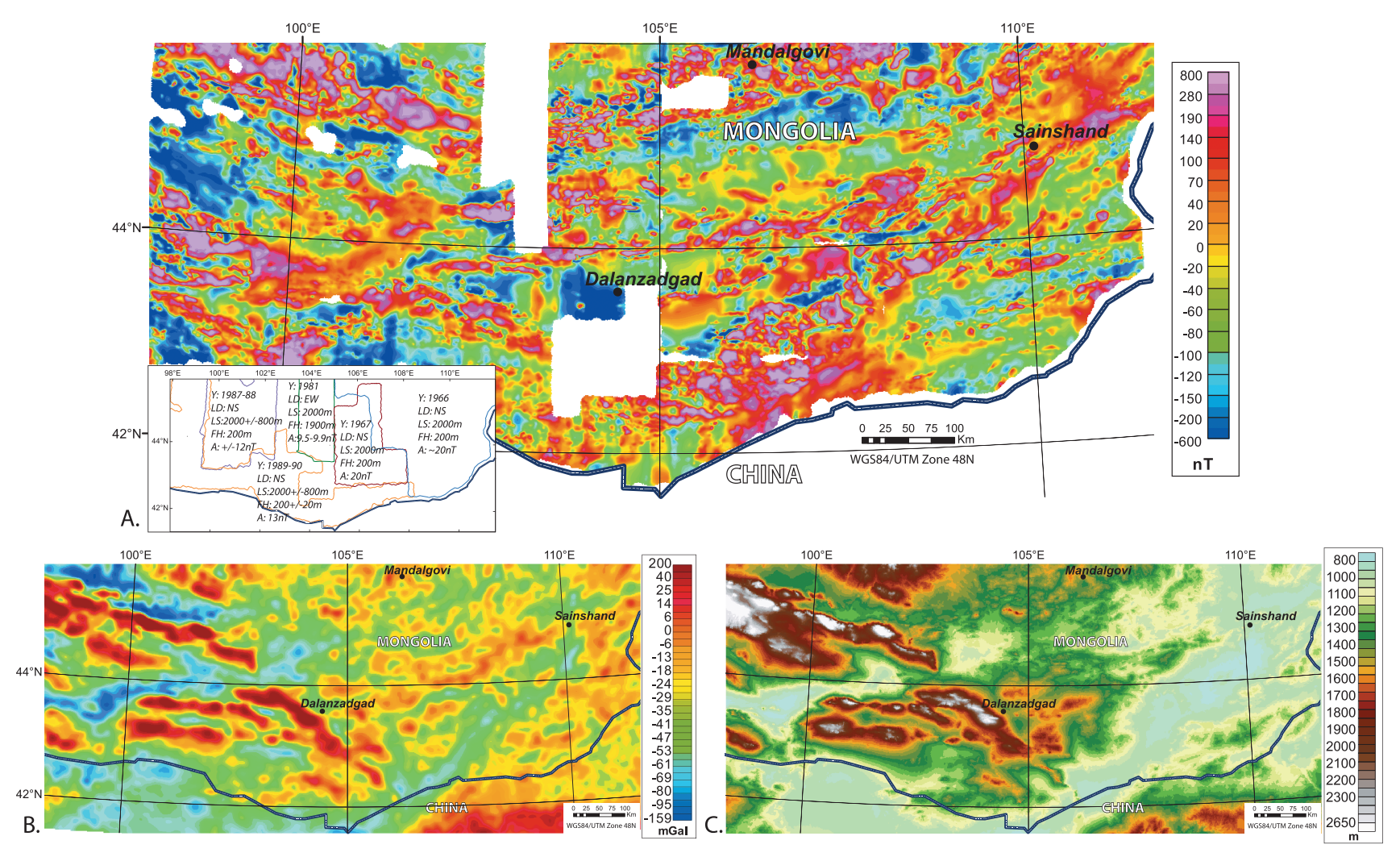

Figure 3. (a) Magnetic anomaly map of southern Mongolia reduced to the pole, leveled and merged. The inset represents the location of the five magnetic grids and the characteristics of the different surveys; (b) free-air anomaly map of southern Mongolia; and (c) the topography map from ETOPO1.

create the free-air anomaly grid have been derived, it is difficult to make a qualitative and quantitative evaluation of the noise contained in the data. The free-air anomalies show a strong correlation with topography (Figure 3c) that tends to conceal the crustal signal. In order to produce a gravity map reflecting the variations in density of continental crust, the topographical effects must be removed from the free-air anomaly data.

\subsubsection{Bouguer Gravity Anomaly}

The complete Bouguer correction, which includes the simple Bouguer [Lafehr, 1991] and the terrain correction [Kane, 1962; Nagy, 1966], has been computed from the free-air anomalies using a mean crustal density of $2670 \mathrm{~kg} / \mathrm{m}^{3}$. The terrain corrections were calculated using a digital elevation model based on ETOPO1 global relief model [Amante and Eakins, 2009] with a grid spacing of 2 min (Figure 3c).

The Bouguer gravity anomalies range from $-245 \mathrm{mGal}$ to $-110 \mathrm{mGal}$ (Figure $4 \mathrm{a}$ ), and three principal zones can be distinguished trending approximately NE-SW. The maximum values of the Bouguer gravity anomalies are located to the southeast of Mongolia forming a large-scale Bouguer gravity anomaly high, whereas the northwest is characterized by a marked Bouguer gravity anomaly low. Between these two gravity domains there is a transitional area marked by the presence of the intermediate NW-SE oriented Bouguer gravity anomalies of large amplitude and short wavelengths. These short-wavelength anomalies mostly coincide with the Palaeozoic mountain ranges. However, the Bouguer anomaly map still contains the long-wavelength signals of the Moho and the upper mantle which conceal the majority of short wavelengths in the gravity signal.

\subsubsection{Isostatic Residual Gravity Anomaly}

The isostatic residual anomaly map (Figure $4 b$ ) enhances the gravity anomalies related to features at crustal level by removing long-wavelength anomalies assumed to be produced by sources in the deep crust or upper mantle [Simpson et al., 1986; Nabighian et al., 2005]. The isostatic residual gravity grid is computed from the Bouguer gravity anomalies using the Airy-Heiskanen compensation model [Heiskanen and Moritz, 1967] with three parameters: (1) the depth of the compensating root of $35 \mathrm{~km}$ at sea level in areas of no topography, (2) a density contrast across the Moho of $330 \mathrm{~kg} / \mathrm{m}^{3}$ [Hinze et al., 2013], and (3) a density of the crustal topography of 


\section{AGU Journal of Geophysical Research: Solid Earth}
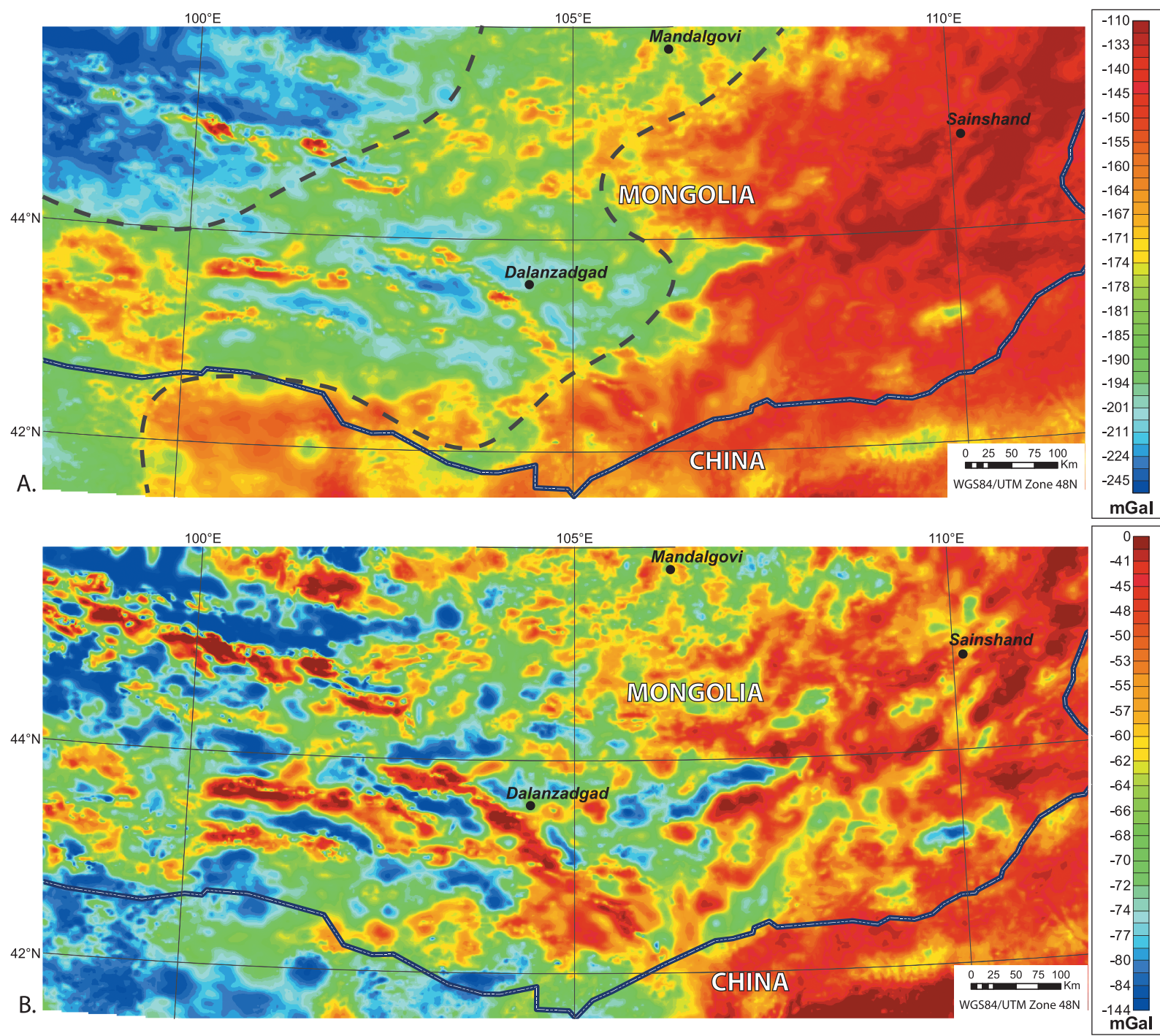

Figure 4. (a) Complete Bouguer anomaly map for the south of Mongolia derived from the free-air anomalies. The dotted lines border the main gravity regions (see description in the text). (b) Isostatic residual anomaly map for the south of Mongolia derived from the Bouguer anomaly map.

$2670 \mathrm{~kg} / \mathrm{m}^{3}$. The resulting isostatic residual anomaly map display short to intermediate wavelengths with amplitudes of around $70 \mathrm{mGal}$. Although the amplitudes of the anomalies are smaller than for the Bouguer anomaly map, the isostatic residual also shows a distinct difference between the northwestern and the southeastern areas which may indicate an important lateral change in the density.

\subsection{Matched Filtering}

The potential field data permit the origin of anomalies to be inferred when correlating different sets of data with surface geology and tectonic features. From a general point of view, the anomalies with long-wavelengths are supposed to be due to sources located in the lower crust or upper mantle, bearing in mind that a wide, shallow source with a gentle inclination can also produce a long-wavelength anomaly. On the contrary, the short-wavelength anomalies are produced by sources located at a shallow level in the crust. However, there is no straightforward correlation between the depth to sources and the gravity and magnetic data.

\subsubsection{Methodology}

The magnetic and gravity anomalies can be described as the sum of sinusoids of different frequencies and amplitudes due to potential sources from shallow to deeper crustal depths. It is therefore possible to identify the level of potential sources and see the lateral variations in density and susceptibility. As a rule, it is 


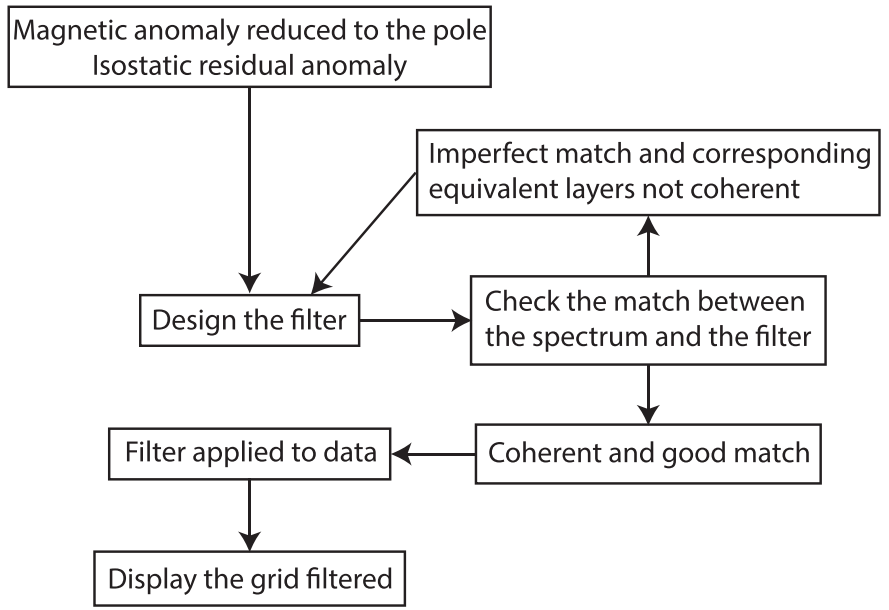

Results for Magnetic anomalies

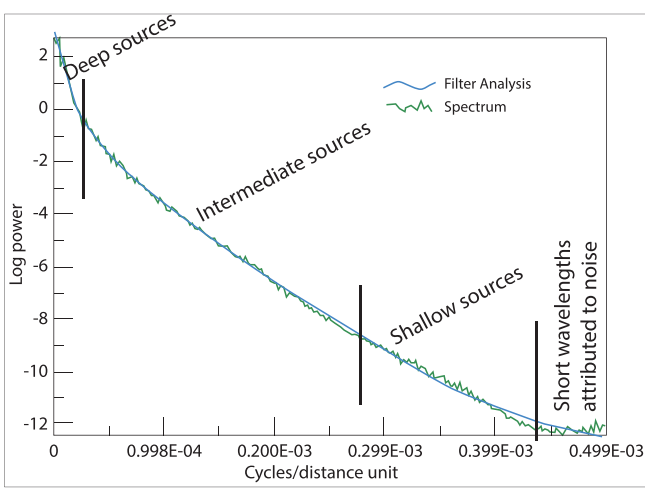

Results for Gravity anomalies

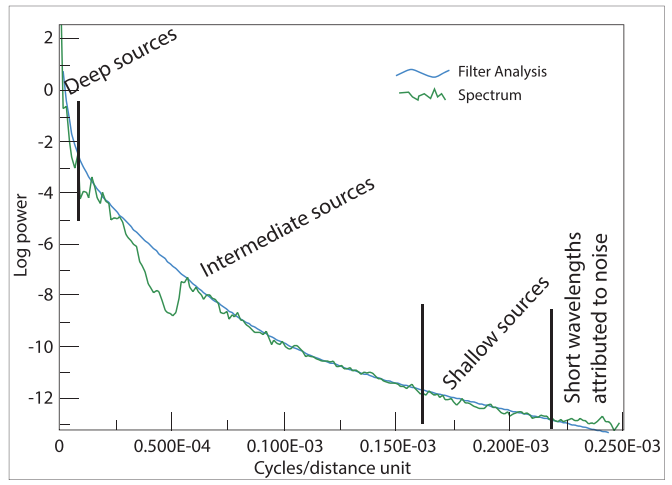

Figure 5. Matched filtering workflow and resulting spectra. (a) Spectra and matched filtering result for magnetic anomalies. (b) Spectra and matched filtering result for isostatic residual anomalies.

admitted that high- and low-frequency anomalies are attributed to shallow depth and deep sources, respectively. The extraction of the magnetic and gravity signal generated at different depth levels can be done using the matched filtering technique [Syberg, 1972; Phillips, 2001]. Matched filtering is a process for detecting the different equivalent potential signal layers at different depth based on the analysis of the Fourier power spectrum of the potential field data. In other words, it is a pseudodepth slicing technique which allows an anomaly separation based on their different wavelengths. The power spectrum of potential data is step by step matched to a model power spectrum (Figure 5) which corresponds to several equivalent layers at different depths [Spector and Grant, 1970]. Each equivalent layer determined by this process corresponds to a band-pass filter which is applied to the data to extract the potential field of the corresponding equivalent layer (Figure 5). Each map displaying the results of the matching band-pass filter should represent the lateral variations of densities and susceptibilities within the corresponding layer. Moreover, the continuity of major crustal structures like sutures across the crustal layer should be observed. Concerning the results for the shallowest part of the crust, some anomalies in this layer seem to be due to aliasing or noise in the original data. However, it is possible to distinguish these distortions from the response of coherent geological fabrics.

The matched filtering of the magnetic and isostatic residual anomaly data (Figures $5 a$ and $5 b$ ) is used to enhance the effects of density and susceptibility variations and contrasts with depth in order to analyze the continuity of geophysical features in depth and the difference of signal between terranes. Therefore, the filtering was applied for the entire area, and the radial spectra of both magnetic and isostatic residual anomaly require a model containing a minimum of three different equivalent layers, which represent shallow, 
intermediate, and deep crustal layers of the observed field. Using this method, the resultant map of each matched filter layer should reflect the variations in rock properties within this layer.

\subsubsection{Pseudodepth Slicing for Magnetic Anomalies}

Figure 6a displays magnetic anomalies produced by magnetic sources with an equivalent layer of dipoles located at a depth of $2.9 \mathrm{~km}$. The intermediate-wavelength map (Figure $6 \mathrm{~b}$ ) corresponds to magnetic sources with a half-space layer located at $5.0 \mathrm{~km}$, and the long-wavelength map (Figure $6 \mathrm{c}$ ) including anomalies from the deepest structures corresponds to an equivalent magnetic half-space located at a depth of $18.3 \mathrm{~km}$. Although some anomalies in these layers most probably result from signal noise, comparison of the geological fabrics with the magnetic signal shows a good correlation. The deepest equivalent layer is compatible with the depth of Curie point for magnetite assuming an average of the geothermal gradient for southern Mongolia [lonov, 2002]. Magnetite is one of the most common magnetic minerals responsible for magnetic susceptibility of rocks and its Curie point is $578^{\circ} \mathrm{C}$ [Clark, 1997]. The rocks below approximately $18 \mathrm{~km}$ probably have very low magnetic susceptibility and thus generate almost no magnetic signal. This implies that the average geothermal gradient should be about $30^{\circ} \mathrm{C} / \mathrm{km}$ that corresponds to a standard continental geotherm.

\subsubsection{Pseudodepth Slicing for Gravity Anomalies}

The gravity spectrum has been fitted to three equivalent layers representing shallow, intermediate, and deep crustal layers (Figure 7). Figure 7a displays isostatic residual anomalies produced by gravity sources located in a density layer located at a depth of $1.5 \mathrm{~km}$. The intermediate-wavelength map (Figure $7 \mathrm{~b}$ ) corresponds to gravity sources located in a density layer at a depth of $7.7 \mathrm{~km}$ and the long-wavelength map (Figure 7c) including anomalies from the deepest features located in a half-space density layer at a depth of $28.5 \mathrm{~km}$. As regards the magnetic results, some anomalies in the equivalent layers could be due to noise in the data. When the matched filtering treatment is applied directly to the Bouguer gravity anomalies, the deepest equivalent layer is about $80 \mathrm{~km}$ in depth and more, because the Bouguer anomaly contains the gravity signal down to the upper mantle. The deepest equivalent layer calculated from the isostatic residual map is at $28.5 \mathrm{~km}$, which lies above the $35 \mathrm{~km}$ that was the input compensating root used to compute this map.

\section{Interpretation of Geophysical Potential Field Images}

\subsection{Magnetic Structures}

The computed isolines for the tilt derivative of the reduced-to the pole magnetic anomalies are superimposed on the magnetic anomaly map (Figure 8b) in order to outline the boundaries of the basement. This map shows an alternation of magnetic highs and lows that can be correlated with the surface geology. Before further interpretation of magnetic signals, several possible ambiguities have to be kept in mind: (1) sedimentary basins (mainly Cretaceous and Cenozoic in age) distributed all over southern Mongolia can attenuate the signals from relics of highly magnetic Palaeozoic arcs, calc-alkaline granitoids, and ophiolites and (2) the high-amplitude magnetic signal from volcano-sedimentary basins, of which there are a few small examples sporadically distributed in the study area, can be superimposed and thus mask the deep magnetic anomalies. These concealed geological structures can be partially deduced by an analysis of the magnetic anomaly map when compared to the tectonic framework of the area. The interpretation of magnetic features is depicted by lineaments in Figure 8. The details of the correlation between lineaments and geological features and their interpretation are summarized in Table 2a.

The analysis of magnetic lineament trends (Figure 8a) reveals a gradual change in strike from WNW-ESE in the western part to ENE-WSW in the eastern part with the inflection located at approximately $104^{\circ}$ of longitude (Figure $8 \mathrm{~b}$ ). The sharp contrasts in the magnetic signal can be correlated with major fault traces, which cannot always be inferred directly in the field. Four major faults can be delineated by marked discontinuities of the magnetic signal: the Gobi-Tienshan fault zone (GT), the Tost fault (T), the Gobi-Onon fault (GO), and the East Gobi Fault Zone (EGFZ). Among the rock units exposed in southern Mongolia, the Palaeozoic sedimentary rocks correlate with a negative magnetic anomaly of low amplitude. On the contrary, the volcanic rocks (Devonian, Late Carboniferous to Early Permian, Permian, Late Jurassic to Early Cretaceous, and Cretaceous) correlate with magnetic highs, except for several areas of Early Carboniferous and Early Permian volcanic rocks particularly in the Noyon area. The Early Permian alkaline granitoids together with Carboniferous calc-alkaline granitoids and ultramafic rocks are strongly magnetized. The Cretaceous and Cenozoic basins sometimes display magnetic highs with rather scattered gradients indicating deeply located 

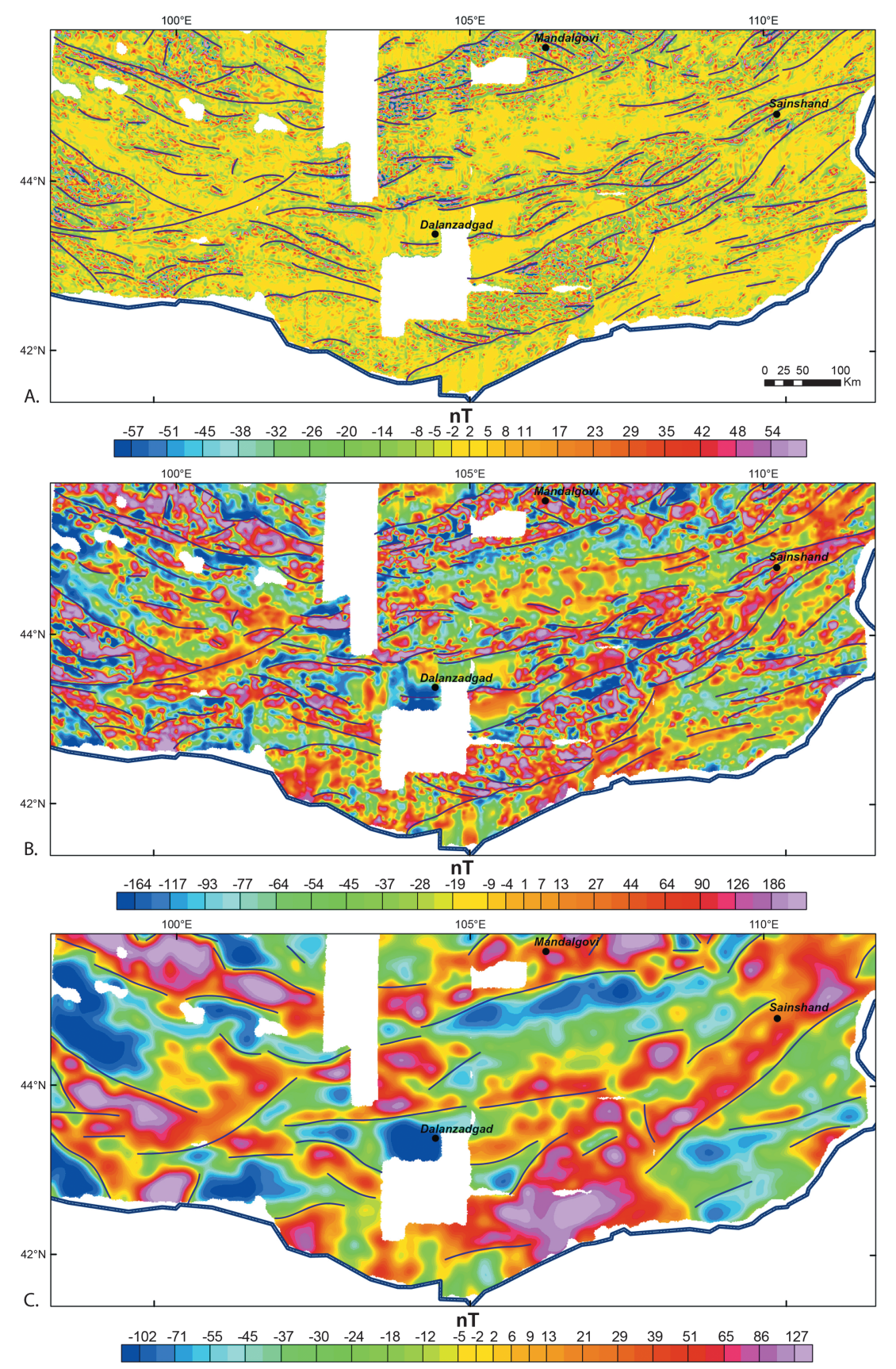

Figure 6. Match-filtered magnetic anomalies reflecting the following: (a) short-wavelength anomalies arising from the shallow source layer at $2.9 \mathrm{~km}$, (b) intermediate-wavelength anomalies from the intermediate source layer at $5 \mathrm{~km}$, and (c) long-wavelength anomalies from the deep source layer at $18 \mathrm{~km}$. The residual magnetic anomaly map displays a series of vertical stripes, which correspond to the N-S oriented flight lines.

magnetic sources. These high-amplitude magnetic trends in the basins do not always coincide with the geology at the surface but seem to mark the continuation of the Palaeozoic outcrops in the substratum of the younger basins.

The alternation of magnetic highs and lows shows a good correlation with the changes in rock type across the region, and some correlation with depth-to-basement might be also present. Therefore, at a large scale, several domains, each with their own geophysical signature (dominant amplitude and frequency) can be identified and delineated (Figure 8b): 


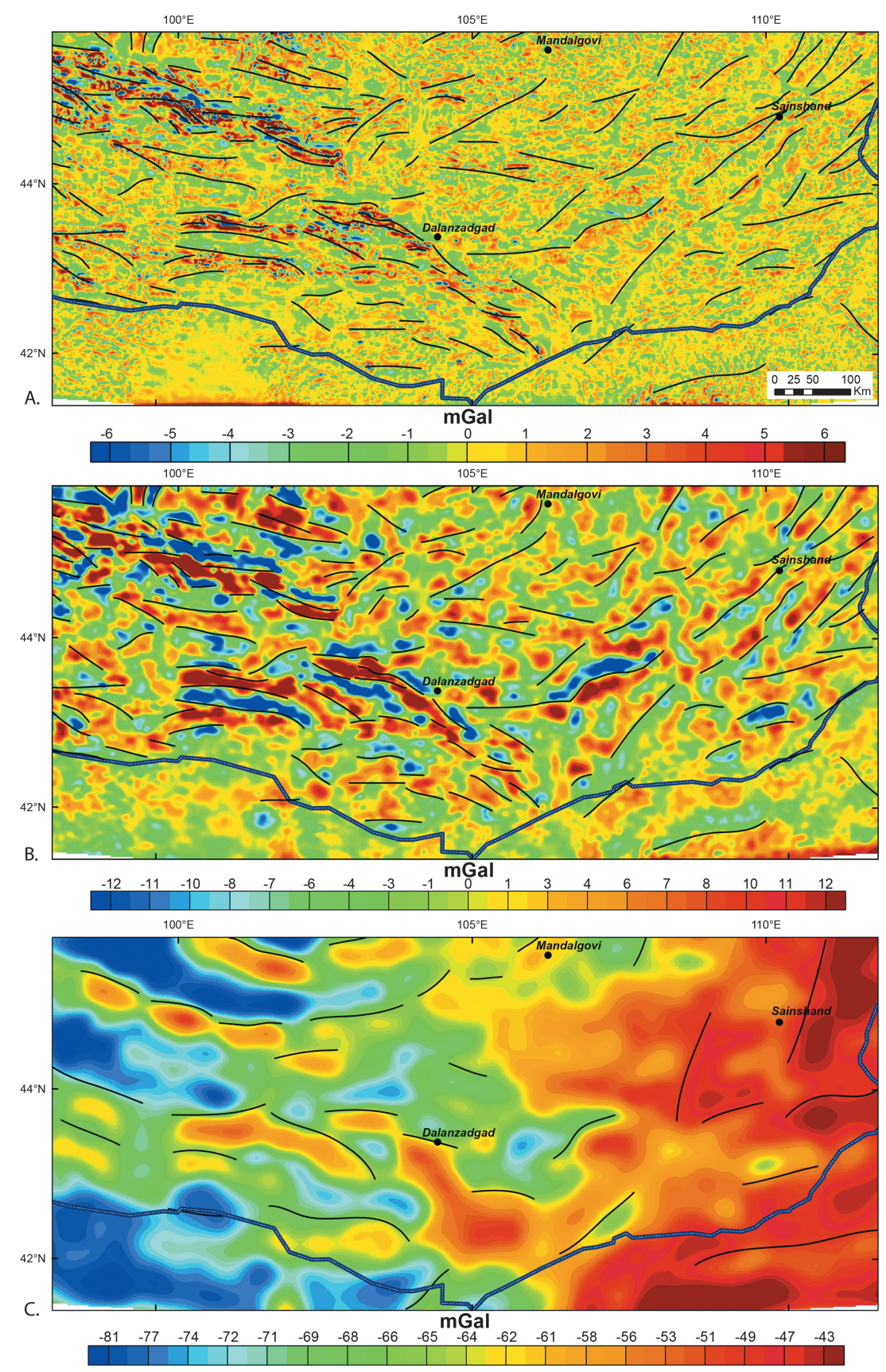

Figure 7. Match-filtered isostatic residual anomaly results reflecting the following: (a) short-wavelength anomalies arising from the shallow source layer at $1.5 \mathrm{~km}$, (b) intermediate-wavelength anomalies from the intermediate source layer at $7.7 \mathrm{~km}$, and (c) long-wavelength anomalies from the deep source layer at $27.1 \mathrm{~km}$.

1. The large magmatic province developed on the Baydrag continent (BY) correlates with a broad magnetic high. It is mostly covered by a wide Cenozoic basin surrounded by small plutons of various ages. This broad positive anomaly continues farther east where it coincides with the Permian-Triassic volcanicplutonic (PTVP) province.

2. The Late Devonian to Early Carboniferous magmatic rocks along the northern edge of the Gobi-Altai Zone $(\mathrm{DM}, \mathrm{CM})$ are marked by a narrow, elongated high-amplitude and high-frequency magnetic anomaly.

3. The large Carboniferous volcanic province (CVP) in the eastern part of the Trans- Altai Zone coincides with a broad magnetic high. 
气ั 造

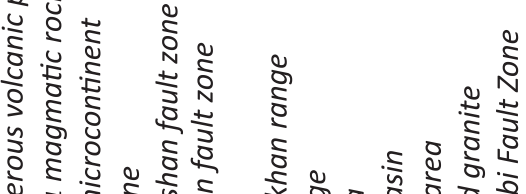

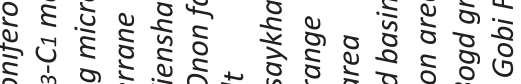
वें

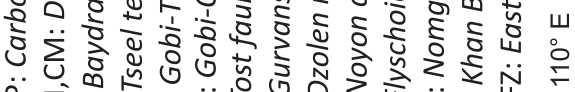

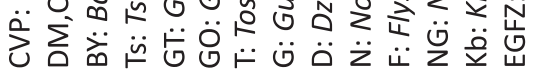
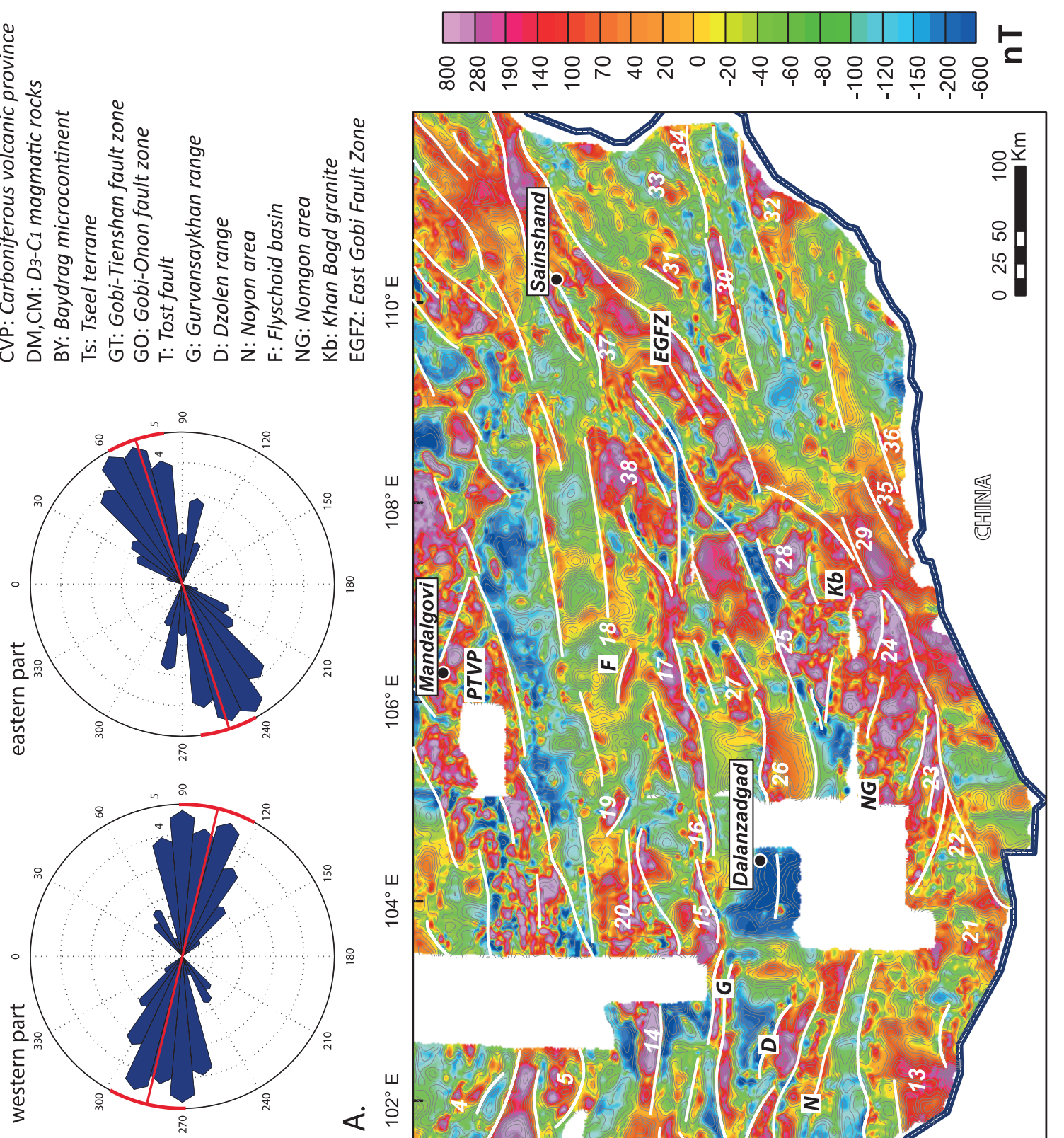

$\stackrel{\varpi}{\circ}$

$w$
$\infty$
$\infty$

(2)
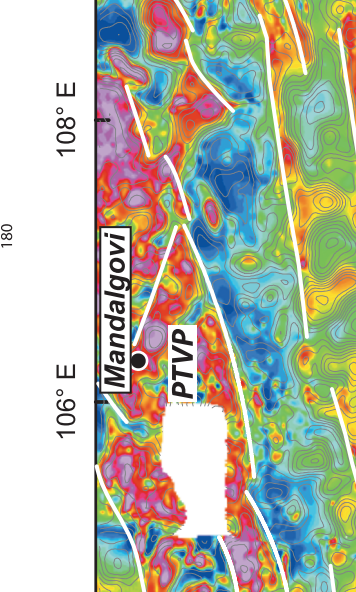

(a)

ש
$\stackrel{2}{\circ}$
$\stackrel{0}{\circ}$

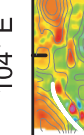

$(251)$
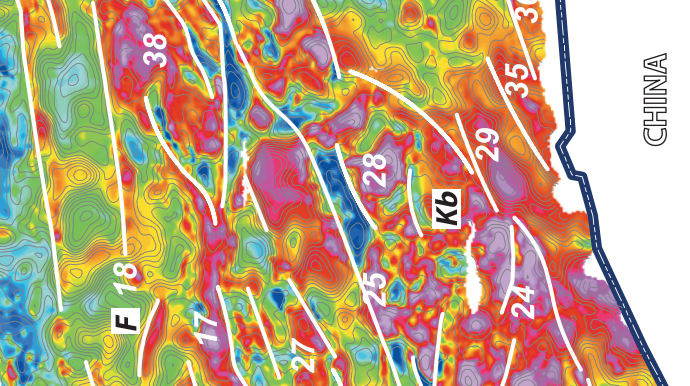
4. The Late Carboniferous to Early Permian magmatic province $(\mathrm{Kb})$ to the southeast is characterized by a wide NE-SW trending magnetic high. This magmatic province continues toward the west where it marks the boundary between the Trans-Altai Zone and the South Gobi Zone (NG) parallel to the trend of the Dzolen unit (D). This Permian magmatic zone corresponds to a narrow WNW-ESE magnetic high.

5. The E-W trending narrow magnetic anomaly is observed north of Dalanzadgad and stretches toward Sainshand town in the east (from numbers 15 to 38). It connects with the major NE-SW trending magnetic high that is correlated with the Late Carboniferous to Permian magmatic province described above. This magnetic anomaly of uncertain origin partly coincides with the occurrence of Permian plutons and volcanic rocks.

\subsection{Gravity Structures}

From the Bouguer anomaly map (Figure 9a) it appears that the large gravity high in the southeast corresponds with the vast region characterized by numerous core complexes, syntectonically intruded by granites and interspersed with basins of Early Cretaceous age [Daoudene et al., 2009]. In contrast, the large gravity low in the northeast occurs at the junction between large-scale anomalies related to the Mongol Altai mountain range to the west and the Hangai in the north [Petit et al., 2002].

The isolines of the tilt derivative of the complete Bouguer gravity anomaly have been superimposed on the isostatic residual anomaly map (Figure 9c) to highlight the boundaries of density units. The interpretation of features in the isostatic residual Bouguer anomaly map (Figure $9 \mathrm{c}$ and Table $2 \mathrm{~b}$ ) shows that the lineaments mainly strike WNW-ESE in the western part and NE-SW in the eastern part (Figure 9b). The analysis of the isostatic residual anomalies reveals the same change in the orientation of lineament trends as seen in the magnetic anomaly map. A significant difference can be observed between the western part of the isostatic residual anomaly map marked by high amplitudes and frequencies of the signal and the eastern part marked by intermediate signal amplitudes and blurred anomalies. Extension during the Cretaceous [Daoudene et al., 2009] could partly explain this salient difference in the pattern of the gravity signal because this deformation may have completely reworked the Palaeozoic orogenic fabric. The western and central parts of the isostatic residual map show an alternation of elongated, narrow positive and negative anomalies oriented in a WNW-ESE direction. The EGFZ, the Gobi-Tienshan, and the Gobi-Onon faults are associated with distinct and strong gravity gradient discontinuities on the isostatic residual anomaly map. Compared to its magnetic expression, the Gobi-Onon fault is not marked by a strong gravity gradient because this is probably masked by a higher-amplitude gravity response produced by the dense Palaeozoic oceanic lithologies forming the Dzolen ridge (Figure 9c). The details of correspondence between gravity signal and geological features are summarized in Table $2 \mathrm{~b}$. The volcanic rocks of all ages correlate with gravity highs, except for several outcrops of Early Carboniferous age. The Middle to Late Carboniferous and Early Permian calc-alkaline granitoids as well as the ultramafic rocks are marked by high-amplitude isostatic residual anomalies. Likewise, in the magnetic anomaly map, several high distinct gravity anomalies are located in the Cretaceous and Cenozoic basins and these anomalies most probably correspond to the buried Palaeozoic rocks that crop out along the margins of the basins.

In conclusion:

1. The region in the northwest is characterized by a periodic alternation of linear gravity highs and lows developed, namely, in the Baydrag basement, the Gobi-Altai Zone, and the northern part of the Trans-Altai Zone. The intensity of the gravity response decreases to the south. The most intense gravity high $(2,3$, and 4$)$ coincides with the occurrence of Devonian gabbroic rocks in the west and Permian volcanic rocks in the east (5 and 6 ).

2. The region in the center shows three distinct positive gravity anomalies covering the southern part of the Trans-Altai Zone and the adjacent South Gobi Zone. These anomalies coincide with the Gurvansaykhan mountain range (G) in the north, the Dzolen range (D) in the center, and the mountain range south of Noyon district (13 and 16). The $G$ and $D$ positive anomalies in the Trans-Altai Zone are related to the presence of Silurian ultramafic rocks while the southernmost anomaly is caused by Carboniferous volcanic rocks.

3. Moving to the east, the contrast in the anomaly pattern is blurred and two distinct types of lineaments are observed ranging from $\mathrm{N} 35^{\circ}$ to $\mathrm{N} 70^{\circ}$ (Figure 9b). The ENE-WSW trending lineaments are discontinuous and seem to be displaced by the NE-SW oriented lineaments represented by straight lines oriented in the range of $\mathrm{N} 20^{\circ}-\mathrm{N} 35^{\circ}$ (Figure $9 \mathrm{c}$ ). 


\section{QAGU Journal of Geophysical Research: Solid Earth}

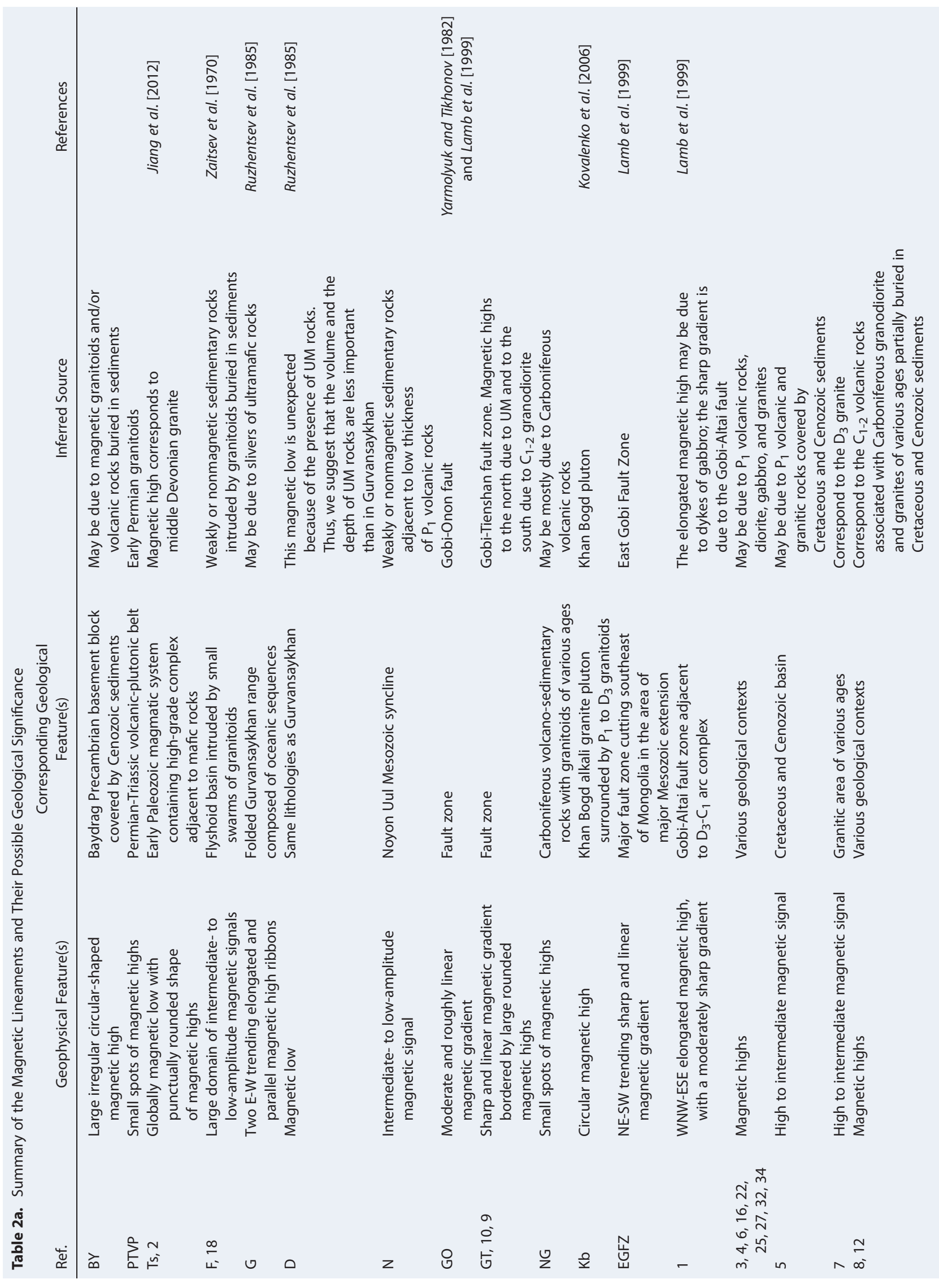




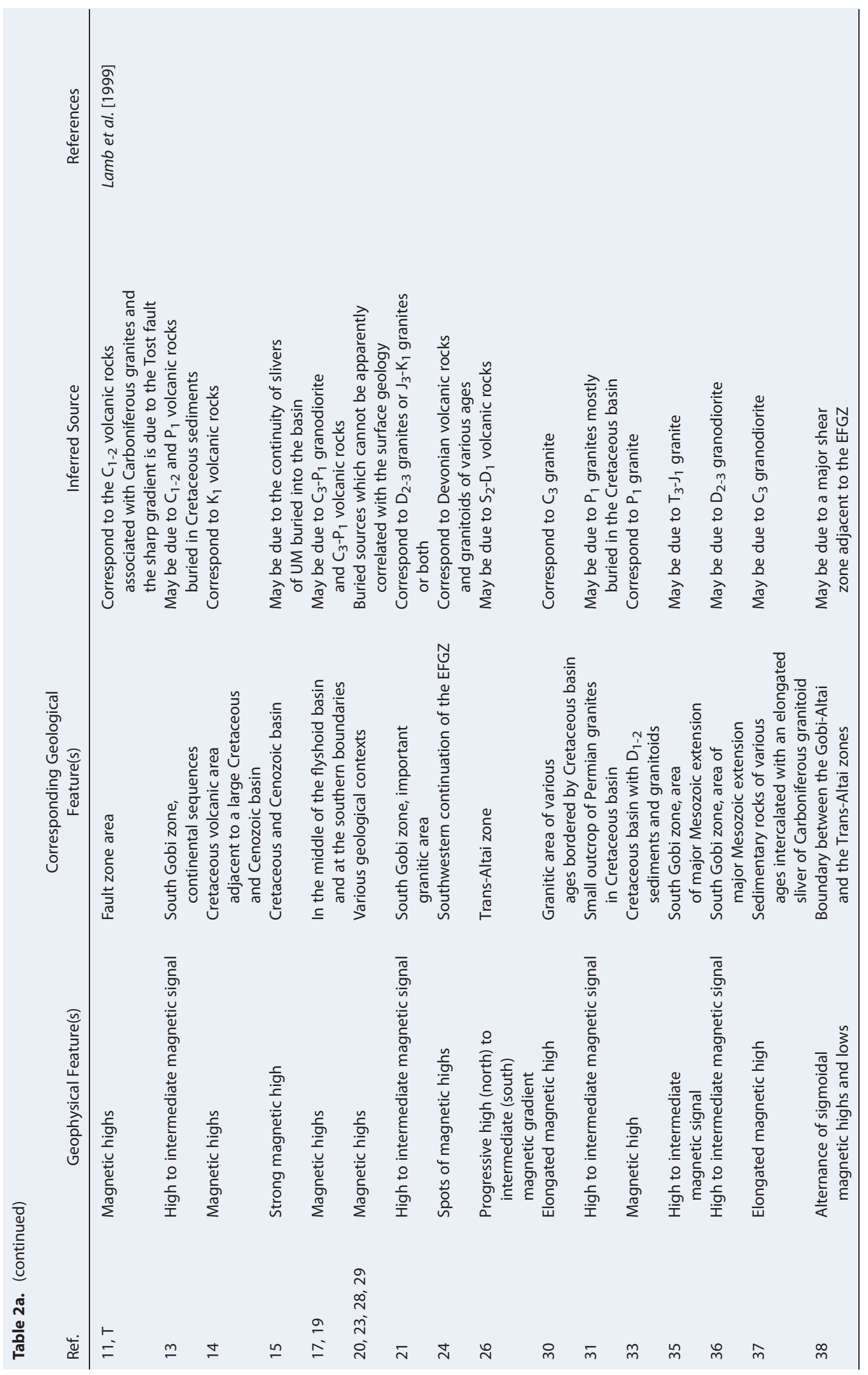




\section{AGU Journal of Geophysical Research: Solid Earth}
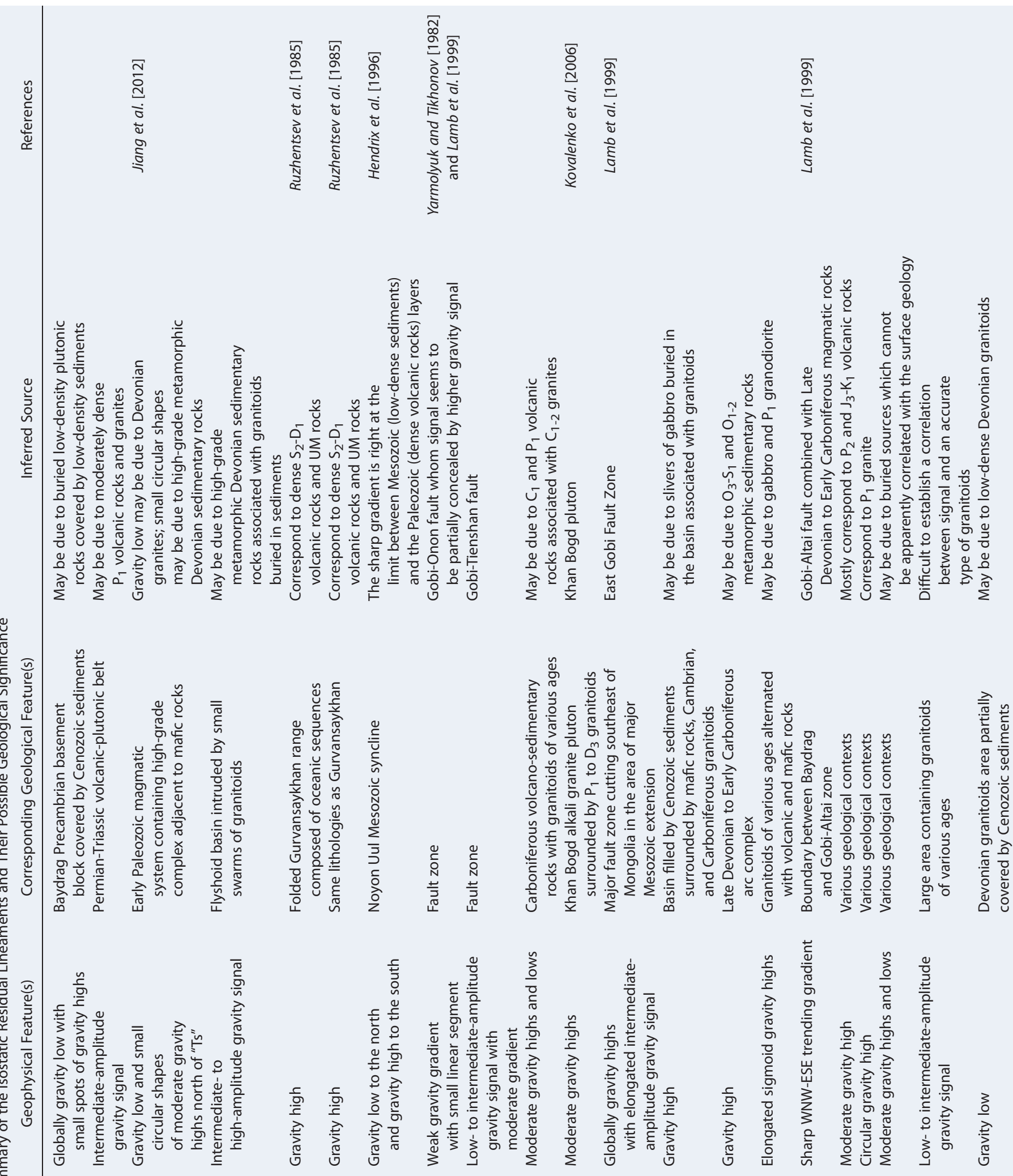

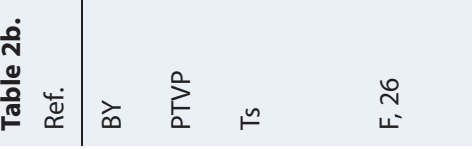




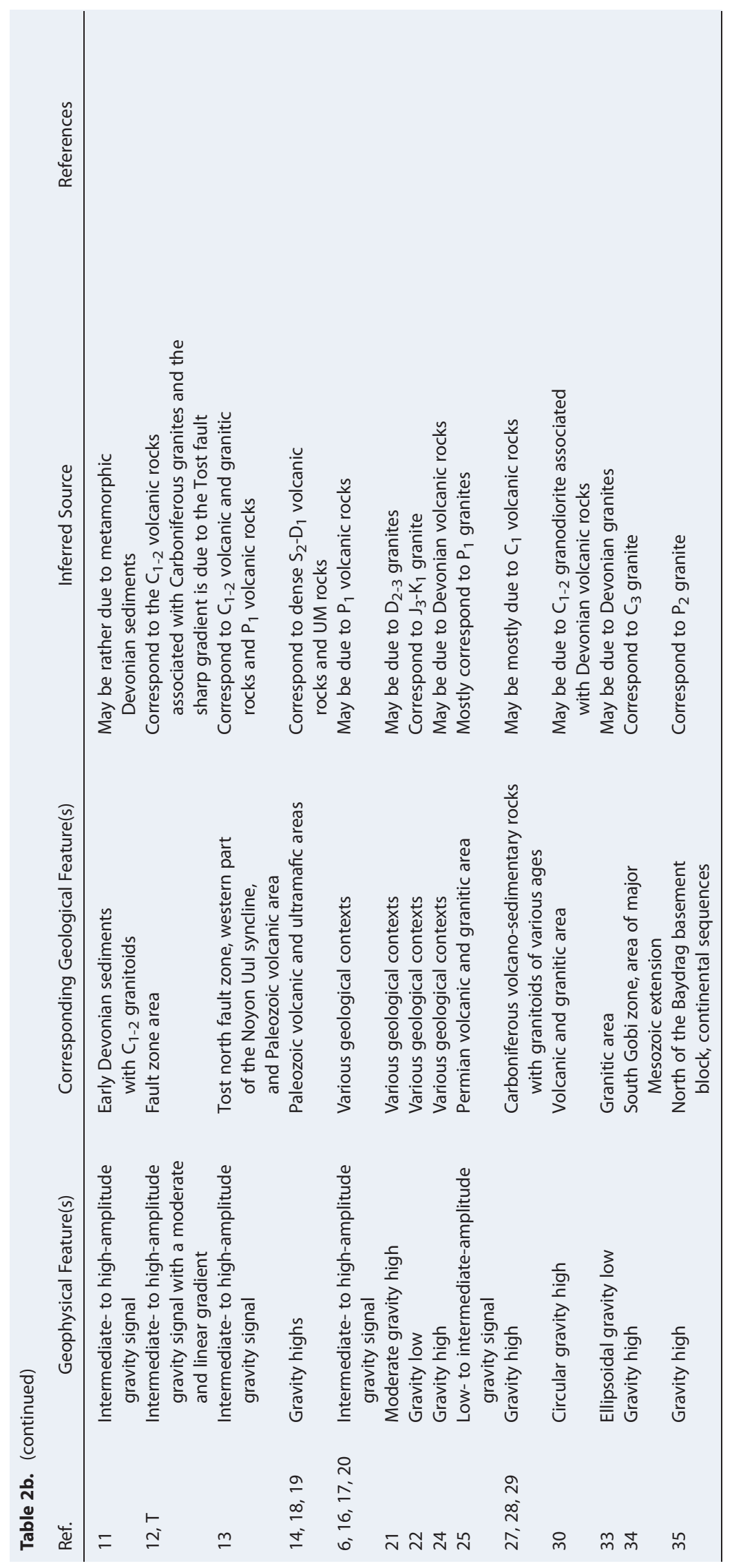



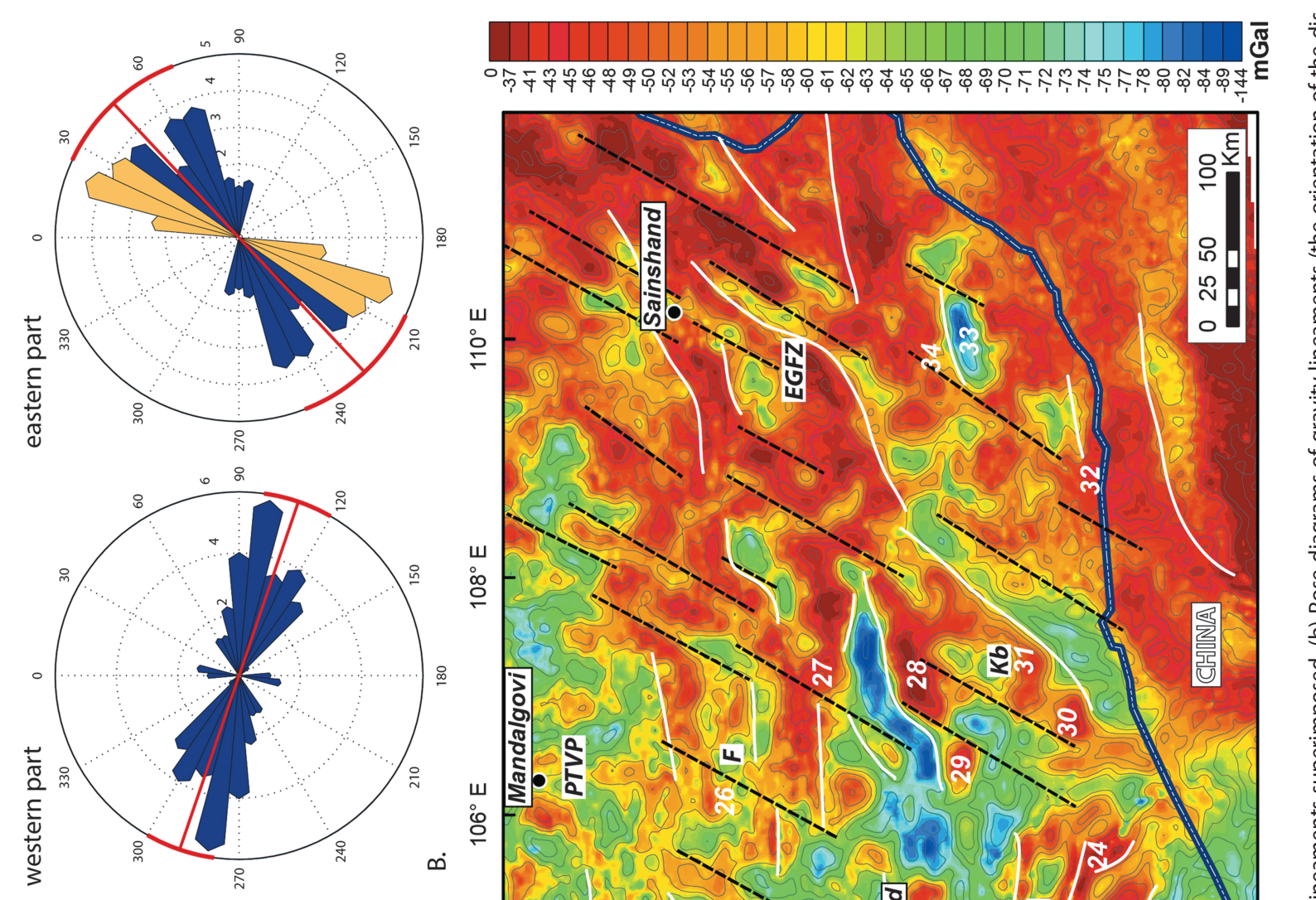

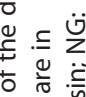

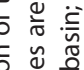

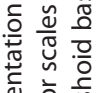

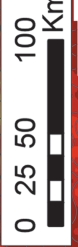

남
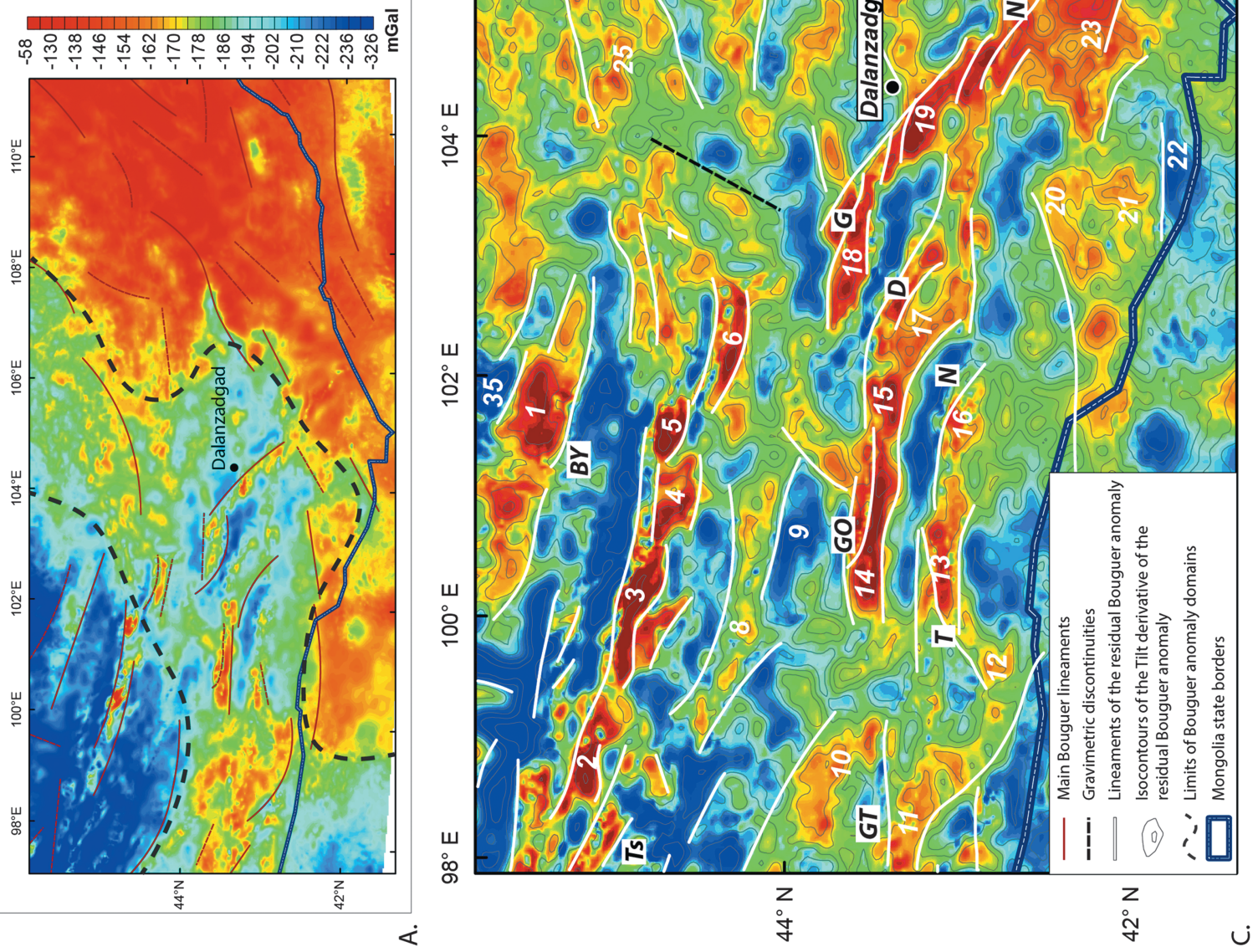

焉它

艺过

है ญे ญ

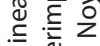

产

तั

पू

继

๘ $\cong$

尊

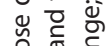

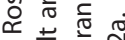

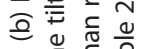

这艺紊它

을 는

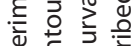

帘 仓ัن

$\stackrel{n}{*}$

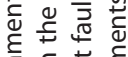

ฮ

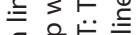

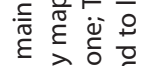

ब충ำ

동 ᅯ

उ $\frac{\pi}{\pi}$ 웅

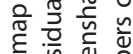

ते

है :

苍芒

屯

วิㄷำ

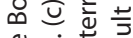

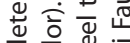

잉

ठั ซึ่

苛苛皆

西. $\cong$

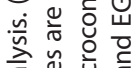

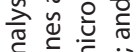

宁望

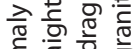

ํํำ

츰

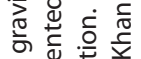

产幽

ठํำ

ดे

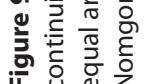




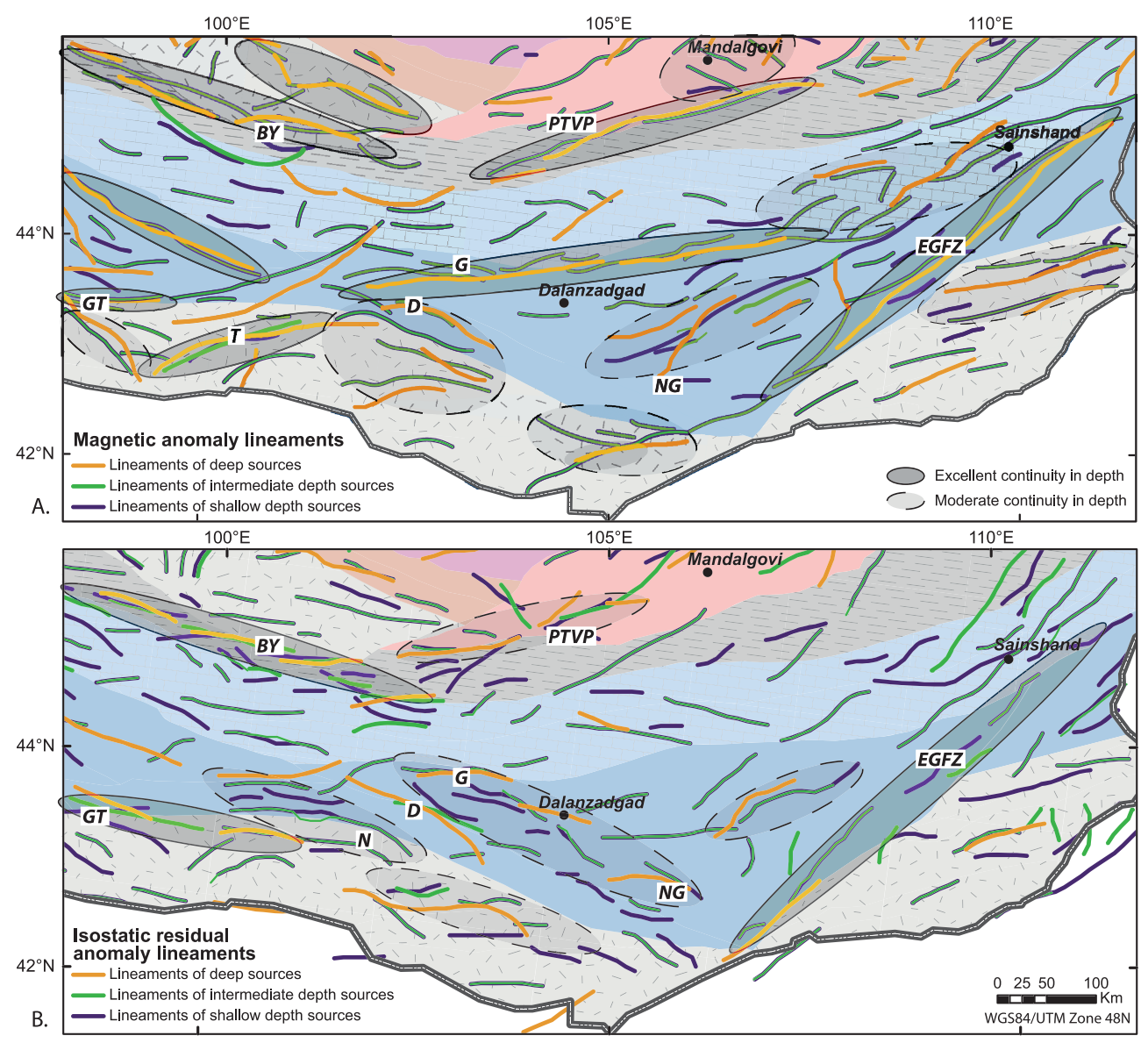

Figure 10. Juxtaposition of the matched filtering lineaments from the different equivalent layers in order to analyze the continuity of geophysical fabrics in depth. In the backgrounds are the tectonic units of southern Mongolia. (a) Magnetic lineaments of matched filtering results. (b) Isostatic residual lineaments of matched filtering results.

\subsection{Deep-Seated Continuity of Magnetic and Gravity Fabrics in the Crust?}

The gravity and magnetic lineaments obtained using the matched filtering technique were superimposed (Figure 10) so that the continuity of geophysical fabrics within the three crustal levels defined above could be compared. Although the analysis of lineaments at deep crustal levels also partly depends on the filtering methods, we can assume that the variations in crustal thickness in southern Mongolia are low, because the seismic studies in the north and central part of Mongolia [Mordvinova et al., 2007; Mordvinova and Artemyev, 2010], and in the north of China [Teng et al., 2013; Zhang et al., 2014], show that the Moho is rather flat at $\sim 45 \mathrm{~km}$ in depth. Areas across which there is an excellent continuity of lineaments at depth are depicted on the maps (Figure 10) by solid ellipses with high aspect ratios, and areas of moderate continuity are depicted by dashed ellipses with lower aspect ratios. The crucial fact revealed by matched filtering of gravity and magnetic data is that the suture zones [Şengör and Natal'in, 1996; Zorin, 1999; Badarch et al., 2002; Štípská et al., 2010; Qu et al., 2011] do not form a strong, deep-seated discontinuity across all crustal levels. Further analysis consisting of modeling the crustal thickness and the lower crustal densities were applied and showed the possible absence of sutures in the deep parts of the crust [Guy, 2012].

The analysis of the lineaments identified by matched filtering of magnetic data reveals an excellent continuity in depth for the major faults in southern Mongolia (EGFZ, T, and GT) as well as for the southern boundaries of the Baydrag microcontinent (BY) and the Permo-Triassic volcanic-plutonic belt (PTVP). The elongated magnetic high in the center of the studied area (G) also has good continuity at depth. The zones with magnetic lineaments of moderate continuity follow the contact between the Trans-Altai Zone and the South Gobi Zone roughly coinciding with the Late Carboniferous to Permian magmatic province (D and NG). 


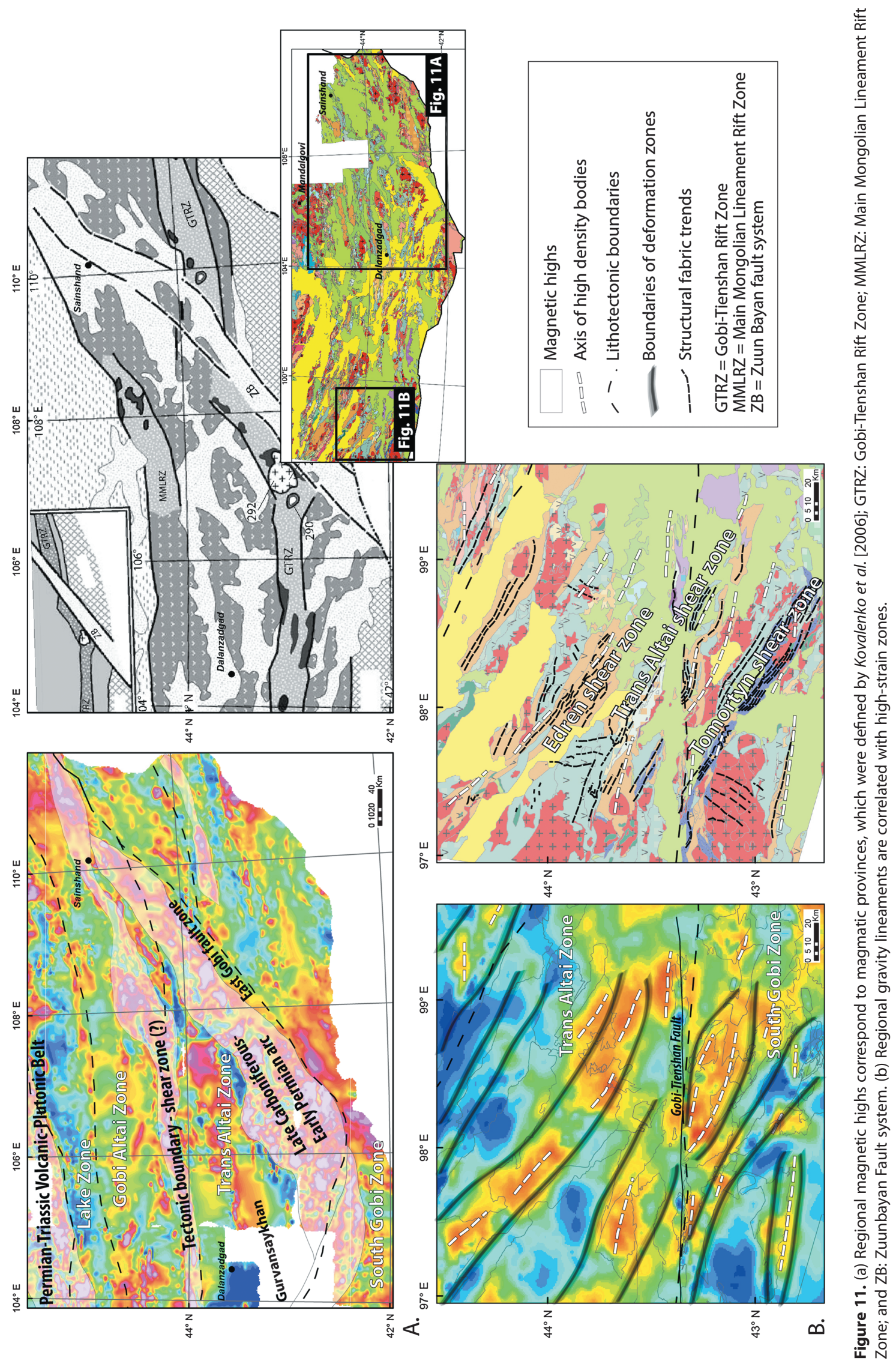




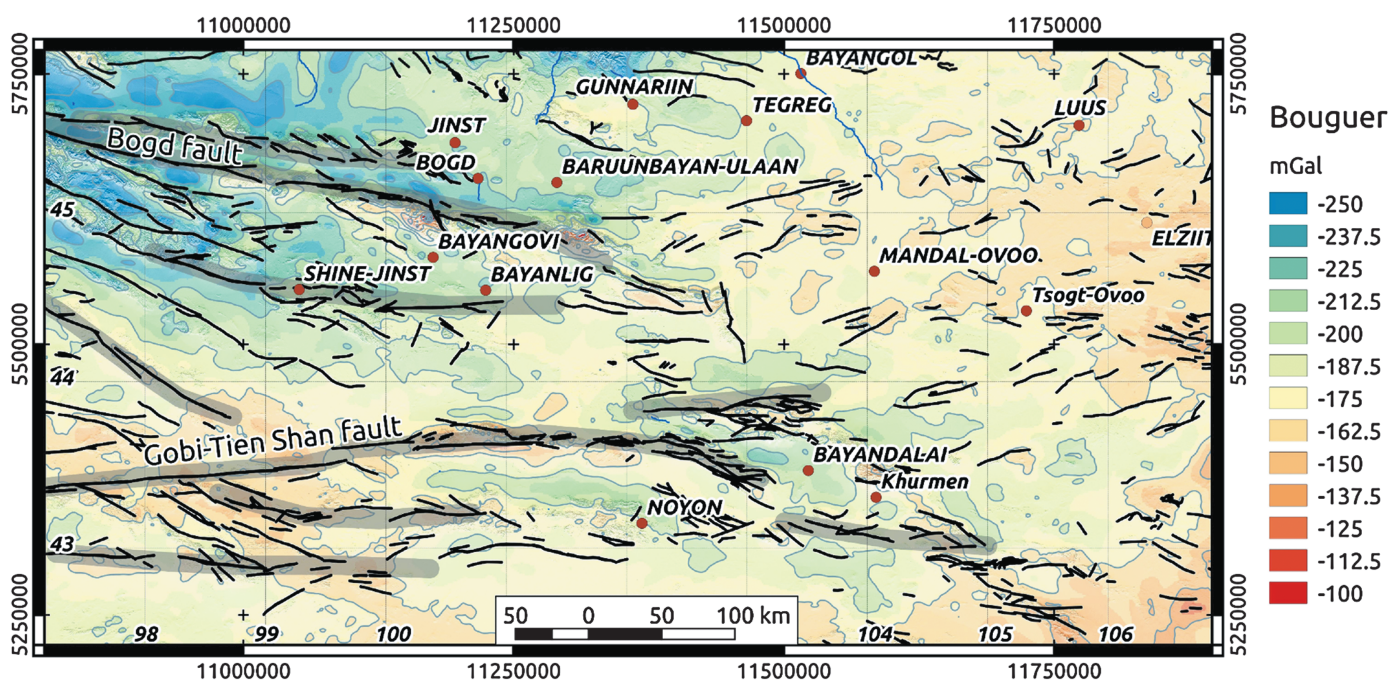

Figure 12. Map of active faults derived from DEM and Landsat imagery superimposed on the Bouguer anomaly map and digital elevation model. The figure shows the coincidence of main mountain ranges, gravity highs, and active fault network interpreted as restraining bends by Cunningham et al. [2009] in the west. The eastern part shows absence of mountain ranges, gravity highs, and significantly more distributed active fault pattern. The grey thick lines are the areas of restraining bends. The black lines are faults visible in Landsat imagery.

Other zones of moderate continuity (ellipse north of NG) are developed in the eastern parts of the Trans-Altai Zone and Gobi-Altai Zone and correspond to the NW margin of a wide magmatic province of Late Carboniferous to Permian age. Finally, to the east of the EGFZ, the analysis shows a zone of moderate continuity corresponding to the Permian magmatic belt developed on the basement of the South Gobi Zone.

A similar analysis of lineaments defined by matched filtering of the gravity data reveals different tendencies, although some gravity lineaments coinciding with faults, like the corresponding magnetic lineaments, show strong continuity at depth (EGFZ and GT). The southern limit of the Baydrag continent is also well defined (BY), whereas the Permo-Triassic volcanic-plutonic belt (PTVP) shows only a moderate continuity of anomalies at depth. There are also three zones of moderate continuity which correspond to three major gravity highs located in the southern Trans-Altai Zone (G and D) and the adjacent South Gobi Zone (N).

\section{Discussion}

First, the significance of the geophysical signals is discussed in relation to the theory of terrane accretion. The possible origin of both magnetic and gravity highs and lows is then considered, and a new geodynamic model for the Mongolian $C A O B$ is proposed, taking into account the geophysical patterns described above.

\subsection{Terranes and Their Geophysical Signature in Southern Mongolia}

By definition, a terrane is an area bounded by steep shear zones, faults, or sutures and characterized by rocks having a stratigraphy, petrology, and/or paleogeography that is distinctly different from the neighboring crustal blocks or continents [Berg et al., 1972, 1978; Coney et al., 1980; Monger et al., 1982; Jones et al., 1983]. Terrane boundaries are often deduced only from the juxtaposition of different lithologies which seem to have no interrelationship. However, Şengör and Dewey [1990] pointed out the problems which can arise when using the term "terrane" to explain tectonic processes, because the lack of accurate definitions means that the terrane concept is not objective. Therefore, it is important to examine whether the Lake Zone, the Gobi-Altai Zone, the Trans-Altai Zone, and the South Gobi Zone can be regarded as "terranes" simply because their lithologies and stratigraphies are different. One way to do this is to compare these terranes with geophysically defined domains. The criteria used to define a geophysical domain are (1) the characteristic trends in the amplitude and frequency of geophysical signals and (2) the unique nature of anomalies in the crust (their gradients and structural features associated with contacts and faults). In summary, a region that shares the same geological, tectonic, and magmatic history will have its own corresponding geophysical pattern. For instance, the geophysical signature of the Tasmanides [Wellman, 1988; Burton, 2010], whom age 


\section{AGU Journal of Geophysical Research: Solid Earth 10.1002/2014JB011026}

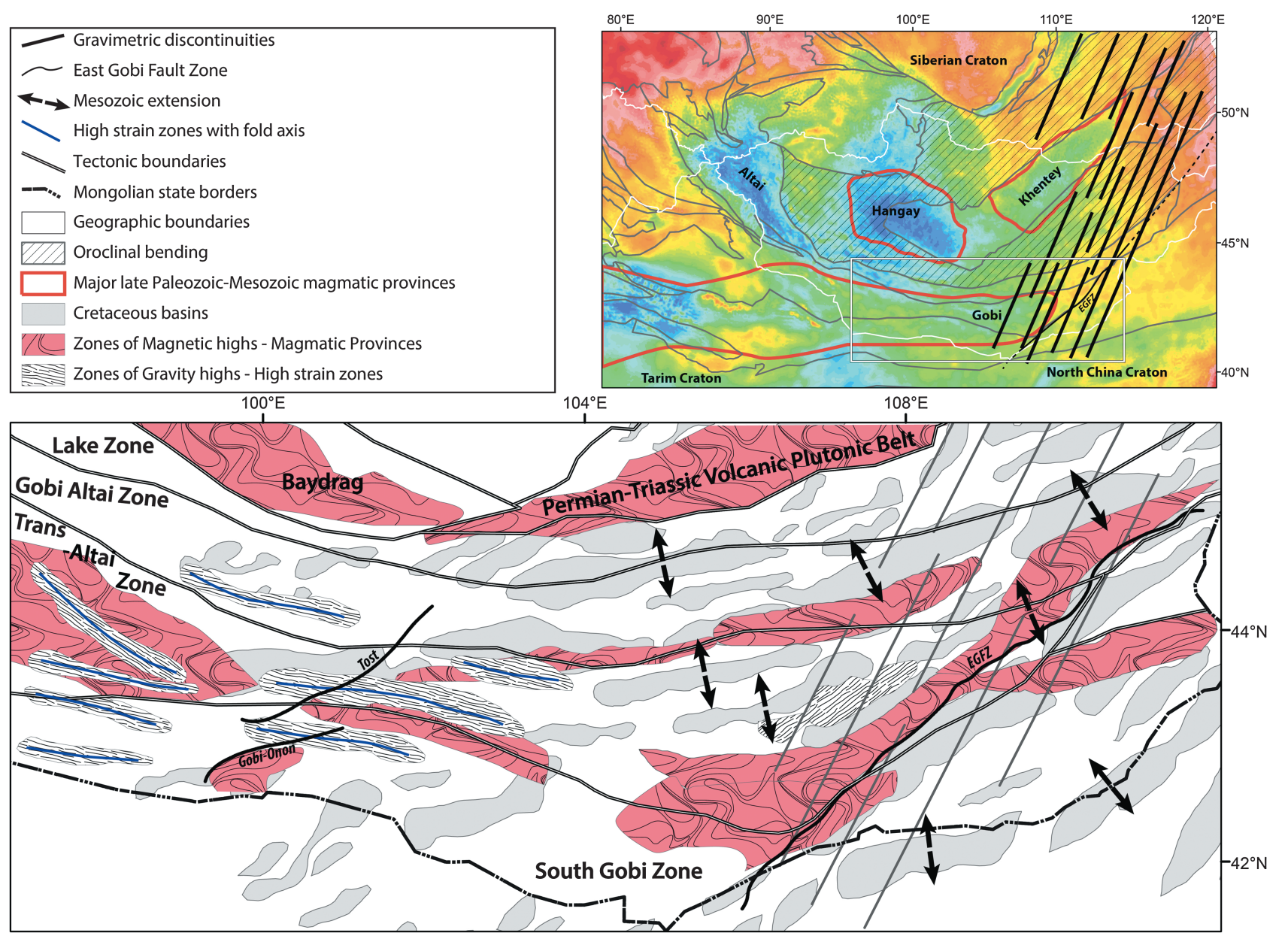

Figure 13. Summary of the potential field fabrics in southern Mongolia. The inset displays the Bouguer anomaly map at the scale of the CAOB.

and accretionary history are similar to those of the CAOB [Schulmann and Paterson, 2011], shows consistent gravity and magnetic domains corresponding to tectonostratigraphically defined terranes.

The south of Mongolia was divided by Badarch et al. [2002] into several volcanic arcs, back arcs and fore arcs, accretionary wedges, ophiolites, and microcontinents designated as terranes accreted along huge sutures and fault zones during the Palaeozoic. Thus, the CAOB in Mongolia is supposed to have grown as a result of accretion of terranes above a series of parallel subduction zones [Badarch et al., 2002; Windley et al., 2007; Xiao et al., 2009]. Indeed, the difference between major tectonic zones is confirmed by their lithostratigraphic composition (Figure 2). However, the existence of terranes in southern Mongolia cannot be demonstrated by the uniformity of their geophysical fabrics because of the lack of systematic correspondence between the high-/low-amplitude and high-/low-frequency geophysical domains and the major terranes. Indeed, the South Gobi Zone, the Gobi-Altai Zone, and, to a certain extent, the Trans-Altai Zone do not display characteristic geophysical patterns which could be attributed to continental, magmatic arc, or oceanic-type terranes. Moreover, it is notable that the trends in magnetic contrast are not necessarily correlated with the trends in the isostatic residual anomaly and certainly not with the regional Bouguer gravity anomaly. In addition, measurements of the geophysical potential fields should clearly reveal any suture zone between adjacent terranes because a prominent deep-seated discontinuity should be present at all crustal levels [e.g., Jones et al., 1983; Banka et al., 2002; Glen et al., 2007b; Edel and Schulmann, 2009]. However, the matched filtering of the magnetic and gravity anomalies in southern Mongolia demonstrates the absence of suture markers at depth. In fact, most of the geophysical signal trends in this region of the $\mathrm{CAOB}$ do not show any direct correlation with the tectonostratigraphic terranes previously identified by Badarch et al. [2002]. 


\subsection{Possible Origin of Magnetic and Gravity Anomalies}

The analysis of magnetic lineaments (Figure 8) shows that the zones of magnetic highs coincide with the Late Carboniferous to Early Permian and Permo-Triassic volcanic-plutonic magmatic provinces. These provinces were previously defined by Kovalenko et al. [2006] and Yarmolyuk et al. [2013] as magmatic rift zones parallel to major boundaries between the Trans-Altai Zone and the Gobi-Altai Zone in the north and the South Gobi Zone in the south. In addition, the magnetic highs north of the Main Mongolian Lineament correspond geographically with the Permian and Triassic magmatic rift zones as defined by Yarmolyuk et al. [2013] (Figure 1). The excellent match between magnetic highs and magmatic rift zones is illustrated in Figure 11a. In addition, the matched filtering shows that the continuity of signal with depth along the boundaries of these high magnetic anomalies is good which may indicate the presence of deeply rooted tectonic zones.

The axes of high-density bodies in the western and central parts of the CAOB under investigation are characterized by the periodic alternation of NW-SE trending high-frequency and high-amplitude gravity anomalies. A comparison of the gravity data with the regional structural geology [Lehmann et al., 2010; Guy et al., 2014] shows that the high-density linear bodies coincide with deformation zones characterized by cleavage fronts up to $20 \mathrm{~km}$ wide. These deformation zones were dated as Late Permian to Triassic [Guy et al., 2014]. In contrast, gravity lows correspond to zones of weak Permo-Triassic deformation that are characterized by subhorizontally inclined fabrics. The excellent match between deformation zones and gravity highs located in the western part of the area under investigation is shown in Figure $11 \mathrm{~b}$. The same correlation between the three gravity highs $(G, D$, and $N$ ) and the large-scale Permo-Triassic deformation zones of Guy et al. [2014] is observed in the central part of the studied area. The matched filtering analysis shows that the largest deformation zones are rooted deeply down to the middle crustal level.

The location of high-frequency and high-amplitude anomalies indicates that the alternations of magnetic and gravity highs and lows can be explained in terms of a succession of deformation zones associated with a large-scale folding affecting the whole of the southern Mongolia [Nikishin et al., 1993; Ruzhentsev, 2001; Delvaux et al., 2013]. For example, the Gurvansaykhan range is structurally defined as a tight to isoclinal upright fold containing slivers of ultramafic and mafic volcanic rocks steepened along a wide vertically foliated zone. A similar structural pattern can be observed in the Dzolen range, which is another upright-folded domain containing vertically foliated ultramafic rocks. Theoretically, verticalization of originally horizontally disposed high-density mafic and ultramafic rocks may form zones with the excess mass responsible for the formation of the observed elongate gravity highs. Such an interpretation is based on assumption that the Moho underneath the studied area is generally flat without major vertical heterogeneities. This assumption is based on horizontal Moho of uniform depth of $\sim 45 \mathrm{~km}$ in the studied region as documented by the receiver function studies of Mordvinova et al. [2007] and Mordvinova and Artemyev [2010] in the northern and central part of Mongolia and by deep seismic sounding [Teng et al., 2013] and seismic reflection profile [Zhang et al., 2014] in northern China.

The map in Figure 12 shows the general spatial fit between elongated gravity highs and mountain ranges in southern Mongolia. The NW-SE trending active faults [Cunningham et al., 2009] shown in this map coincide with the orientation of Permo-Triassic shear zones described by Lehmann et al. [2010] in the western part of the study area and with the major zones of Permo-Triassic deformation in the Gurvansaykhan and Dzolen ranges in the southern Mongolia [Guy et al., 2014]. These mountain ranges are interpreted by Cunningham et al. [2009] as restraining bends related to sinistral movements along large-scale E-W trending active faults, e.g., the Gobi Tien Shan and Bogd faults (Figure 12). As previously discussed, the Permo-Triassic shear zones coincide with gravity highs due to the thickening of high-density oceanic crust relics forming the upper crustal section of the Trans-Altai Zone. Therefore, we suggest that the localization of restraining bends is controlled by the regional distribution of these vertical Permo-Triassic shear zones. It should be mentioned that even if the mountain ranges were elevated via vertical uplift within restraining bends, the heavy roots of the vertical shear zones remain preserved.

In contrast, the eastern part of the studied area shows almost complete obliteration of the Permo-Triassic tectonic pattern as well as corresponding geophysical signature owing to Cretaceous extensional tectonics [Daoudene et al., 2009]. This corroborates with the different pattern of Cenozoic and active faults compared to the western segment (Figure 12) which are more distributed, shorter, and not related to topographical variations. This is 
because the new extensional fabric is oriented in the NE-SW direction [Daoudene et al., 2009, 2012], i.e., close to the principal plane of recent compressive stress which precludes reactivation of these Permo-Triassic structures.

\subsection{Geodynamic Implications}

The geophysical interpretation presented above, combined with structural and geochronological studies, has provided insights into the tectonic evolution of southern Mongolia. The lithospheric-scale gravity lows are spatially related to the Permian Hangay [Petit et al., 2002] and the Triassic Khentey magmatic provinces [Yarmolyuk et al., 2013]. A similar gravity low of less intensity is also developed in southern Mongolia and corresponds spatially to the Tarim-southern Mongolian zone of the Late Carboniferous to Permian magmatic province defined by Economos et al. [2012] and Yarmolyuk et al. [2013]. This area is described as a region of Permian to Triassic rift-related magmatism by Kovalenko et al. [2006]. The present investigation demonstrates that there is a regional distribution of magnetic highs in southern Mongolia that matches these zones of Permo-Triassic magmatism. Therefore, it is proposed that the large-scale gravity low and the array of linear magnetic highs reflect this lithospheric-scale magmatic event (Figures 12 and 13).

The distribution of linear gravity and, to a lesser extent, magnetic anomalies in the western part of the study area of the CAOB spatially coincides with the deformation zones of the Late Permian to Early Jurassic age (Figure 13). These zones were interpreted to be the result of the compression between the Siberian craton in the north and the North China-Tarim cratons in the south [Lehmann et al., 2010]. Generally, the ENE-WSW strike of gravity and magnetic anomalies in the eastern part of the studied area is modified by the NE-SW trending geophysical discontinuities. These discontinuous zones spatially and geometrically coincide with sinistral strike-slip zones of the Late Triassic to Jurassic age (e.g., the East Gobi Fault Zone) [Lamb et al., 1999; Webb and Johnson, 2006] parallel to the eastern boundary of the Siberia craton. During the Cretaceous, continental extension occurred in the east of Asia, affecting the eastern part of southern Mongolia more than the western part [Zorin, 1999; Ren et al., 2002; Meng, 2003]. This extension led to the development of sedimentary basins [Johnson et al., 2001; Graham et al., 2001; Ren et al., 2002; Webb and Johnson, 2006] and the exhumation of metamorphic core complexes in wide rift basins [Daoudene et al., 2009; Charles et al., 2012]. We assume that this lithospheric-scale event may be responsible for the origin of the wide gravity high covering the whole of eastern Asia in agreement with the receiver function studies of Chen et al. [2008].

\section{Conclusions}

The analysis of the gravity and magnetic anomalies combined with the stratigraphic and structural observations and new interpretations provides new insights into the crustal structure beneath the south of Mongolia. A general observation can be made from the features of the geophysical anomalies and the likely depth of their sources. The residual magnetic anomalies correspond to the shallow structures and the boundaries of the tectonic units, whereas the gravity anomalies mostly represent the deep-laying sources. This is partly because the magnetic field attenuates faster than the gravity field with distance from the source and also due to the lower spatial resolution of the gravity data compared with the resolution of the magnetic data. The gravity and magnetic lineaments have been defined at a regional scale revealing the change in orientation from WNW-ESE strike in the west to NE-SW strike in the east. A comparison between the new 1:500,000 scale geological map and the processed gravimetric and magnetic data for the same area was made. Although some lineaments are correlated with Neogene fault systems, the comparison shows at a large scale that the geophysical signatures of the gravity and magnetic anomalies do not accurately match the tectonostratigraphic terranes which have been previously assumed to make up the CAOB. In southern Mongolia, overall, the magnetic highs coincide with Late Carboniferous to Early Permian-Triassic volcanic and plutonic provinces, whereas the gravity highs correspond with late Permian to Triassic zones of high strain. The tectonic boundaries defined by potential field data therefore do not necessarily correspond with the boundaries of terranes marked by changes in lithostratigraphy. For this reason, the quasi-systematic use of terranes for the purpose of geodynamic modeling in the CAOB may not be well adapted to the interpretation of the tectonic evolution of southern Mongolia. It is suggested that the delineation of terranes proposed for southern Mongolia should be reexamined, taking into account the geophysical data now available. 


\section{Acknowledgments}

We would like to thank the two reviewers, Jörg Ebbing and Stanislaw Mazur, for their detailed and constructive comments that helped us to improve the paper and Michael Walter for his editorial work. The authors would like to thank Ole Balthazar Andersen and the Technical University of Denmark who kindly provided the gravity data and GETECH for the magnetic data. The preparation of this manuscript was supported by the Grant Agency of Czech Republic project P210/12/2205 to Karel Schulmann. Financial support provided by AREVA to Alexandra Guy is also acknowledged. The support received by K.S. from the Ministry of Education of the Czech Republic (grant LK11202) is also gratefully acknowledged. We also thank Chris Halls for his careful review and Martin Staněk for his comments on an earlier draft. This is a contribution to IGCP Project 592 sponsored by IUGS and UNESCO.

\section{References}

Amante, C., and B. W. Eakins (2009), ETOPO1 1 arc-minute global relief model: Procedures, data Sources and analysis, NOAA Tech. Memo. NESDIS NGDC, 24, 19.

Andersen, O. B., and P. Knudsen (2009), DNSC08 mean sea surface and mean dynamic topography models, J. Geophys. Res., 114, C11001, doi:10.1029/2008JC005179.

Badarch, G., C. W. Cunningham, and B. F. Windley (2002), A new terrane subdivision for Mongolia: Implications for the Phanerozoic crustal growth of Central Asia, J. Asian Earth Sci., 21(1), 87-110.

Banka, D., T. C. Pharaoh, and J. P. Williamson (2002), Potential field imaging of Palaeozoic orogenic structure in northern and central Europe, Tectonophysics, 360(1-4), 23-45.

Berg, H. C., D. L. Jones, and D. H. Richter (1972), Gravina-Nutzotin Belt; tectonic significance of an upper Mesozoic sedimentary and volcanic sequence in southern and southeastern Alaska, in Geological Survey Research 1972, U.S. Geol. Surv. Prof. Pap., 800-D, D1-D24.

Berg, H. C., D. L. Jones, and P. J. Coney (Eds.) (1978), Map showing pre-Cenozoic tectonostratigraphic terranes of southeastern Alaska and adjacent areas, U.S. Geol. Surv. Open File Rep., 78-1085, 2 sheets, scale 1:1,000,000 ed.

Burton, G. R. (2010), New structural model to explain geophysical features in northwestern new south wales: Implications for the tectonic framework of the Tasmanides, Aust. J. Earth Sci., 57(1), 23-49.

Cawood, P. A., A. Kröner, W. J. Collins, T. M. Kusky, W. D. Mooney, and B. F. Windley (2009), Accretionary orogens through Earth history, in Earth Accretionary Systems in Space and Time, edited by P. A. Cawood and A. Kröner, Geol. Soc. London Spec. Publ., 318, 1-36.

Charles, N., C. Gumiaux, R. Augier, Y. Chen, M. Faure, W. Lin, and R. Zhu (2012), Metamorphic Core Complex dynamics and structural development: Field evidences from the Liaodong Peninsula (China, East Asia), Tectonophysics, 560-561(0), 22-50.

Chen, L., W. Tao, L. Zhao, and T. Zheng (2008), Distinct lateral variation of lithospheric thickness in the Northeastern North China Craton, Earth Planet. Sci. Lett., 267(1-2), 56-68.

Clark, D. A. (1997), Magnetic petrophysics and magnetic petrology: Aids to geological interpretation of magnetic surveys, J. Aust. Geol. Geophys., 17(2), 83-103.

Coney, P. J., D. L. Jones, and J. W. H. Monger (1980), Cordilleran suspect terranes, Nature, 288(5789), 329-333.

Cunningham, D., S. Davies, and D. McLean (2009), Exhumation of a Cretaceous rift complex within a Late Cenozoic restraining bend, southern Mongolia: Implications for the crustal evolution of the Gobi Altai region, J. Geol. Soc., 166(2), 321-333.

Daoudene, Y., D. Gapais, P. Ledru, A. Cocherie, S. Hocquet, and T. V. Donskaya (2009), The Ereendavaa Range (north-eastern Mongolia): An additional argument for Mesozoic extension throughout eastern Asia, Int. J. Earth Sci., 98(6), 1381-1393.

Daoudene, Y., D. Gapais, G. Ruffet, E. Gloaguen, A. Cocherie, and P. Ledru (2012), Syn-thinning pluton emplacement during Mesozoic extension in eastern Mongolia, Tectonics, 31, TC3001, doi:10.1029/2011TC002926.

Delvaux, D., S. Cloetingh, F. Beekman, D. Sokoutis, E. Burov, M. M. Buslov, and K. E. Abdrakhmatov (2013), Basin evolution in a folding lithosphere: Altai-Sayan and Tien Shan belts in Central Asia, Tectonophysics, 602(0), 194-222.

Dewey, J. F. (1977), Suture zone complexities: A review, Tectonophysics, 40(1-2), 53-67.

Didenko, A. N., A. A. Mossakovsky, D. M. Pechersky, S. V. Ruzhentsev, S. G. Samygin, and T. N. Kheraskova (1994), Geodynamics of Paleozoic oceans of Central Asia [in Russian], Russ. Geol. Geophys., 35(7-8), 59-75.

Economos, R. C., S. R. Paterson, L. O. Said, M. N. Ducea, J. L. Anderson, and A. J. Padilla (2012), Gobi-Tianshan connections: Field observations and isotopes from an early Permian arc complex in southern Mongolia, Geol. Soc. Am. Bull., 124(11-12), 1688-1701.

Edel, J. B., and K. Schulmann (2009), Geophysical constraints and model of the "Saxothuringian and Rhenohercynian subductions, magmatic arc system" in NE France and SW Germany, Bull. Soc. Geol. Fr., 180(6), 545-558.

Glen, J. M. G., J. Schmidt, and R. Morin (2007a), Gravity and magnetic character of south-central Alaska: Constraints on geologic and tectonic interpretations, and implications for mineral exploration, Geol. Soc. Am. Spec. Pap., 431, 593-622.

Glen, J. M. G., J. Schmidt, L. Pellerin, D. K. McPhee, and J. M. O’Neill (2007b), Crustal structure of Wrangellia and adjacent terranes inferred from geophysical studies along a transect through the northern Talkeetna Mountains, Geol. Soc. Am. Spec. Pap., 431, 21-41.

Graham, S. A., M. S. Hendrix, C. L. Johnson, D. Badamgarav, G. Badarch, J. Amory, M. Porter, R. Barsbold, L. E. Webb, and B. R. Hacker (2001), Sedimentary record and tectonic implications of Mesozoic rifting in southeast Mongolia, Geol. Soc. Am. Bull., 113(12), $1560-1579$.

Guy, A. (2012), Geological and geophysical characterization of accretionary and collisional systems: The Central Asian Orogenic Belt and the Bohemian Massif, 270 pp., Univ. of Strasbourg, Strasbourg, France.

Guy, A., K. Schulmann, N. Clauer, P. Hasalová, R. Seltmann, R. Armstrong, O. Lexa, and A. Benedicto (2014), Late Paleozoic-Mesozoic tectonic evolution of the Trans-Altai and South Gobi Zones in southern Mongolia based on structural and geochronological data, Gondwana Res., 25, 309-337.

Heiskanen, W. A., and H. Moritz (1967), Physical Geodesy, pp. 364, W. H. Freeman and Company, San Francisco, Calif.

Hendrix, M. S., S. A. Graham, J. Y. Amory, and G. Badarch (1996), Noyon Uul syncline, southern Mongolia: Lower Mesozoic sedimentary record of the tectonic amalgamation of central Asia, Bull. Geol. Soc. Am., 108(10), 1256-1274.

Hinze, W. J., R. R. B. von Frese, and A. H. Saad (2013), Gravity and Magnetic Exploration: Principles, Practices, and Applications, Cambridge Univ. Press, Cambridge, New York.

Ionov, D. (2002), Mantle structure and rifting processes in the Baikal-Mongolia region: Geophysical data and evidence from xenoliths in volcanic rocks, Tectonophysics, 351(1-2), 41-60.

Jiang, Y., M. Sun, A. Kröner, D. Tumurkhuu, X. Long, G. Zhao, C. Yuan, and W. Xiao (2012), The high-grade Tseel Terrane in SW Mongolia: An Early Paleozoic arc system or a Precambrian sliver?, Lithos, 142-143(0), 95-115.

Johnson, C. L., L. E. Webb, S. A. Graham, M. S. Hendrix, and G. Badarch (2001), Sedimentary and structural records of late Mesozoic high-strain extension and strain partitioning, East Gobi basin, southern Mongolia, Geol. Soc. Am. Mem., 194, 413-433.

Jones, D. L., D. G. Howell, P. J. Coney, and J. W. H. Monger (1983), Recognition, character, and analysis of tectonostratigraphic terranes in western North America, in Accretion Tectonics in the Circum-Pacific Region: Proceedings of the Oji International Seminar on Accretion Tectonics, Japan, 1981, Adv. Earth Planet. Sci., edited by M. Hashimoto and S. Uyeda, pp. 21-35, Terra Sci., Tokyo.

Kane, M. F. (1962), A comprehensive system of terrain corrections using a digital computer, Geophysics, 27(4), 455-462.

Kovalenko, V. I., V. V. Yarmoluyk, E. B. Sal'nikova, A. M. Kozlovsky, A. B. Kotov, V. P. Kovach, V. M. Savatenkov, N. V. Vladykin, and V. A. Ponomarchuk (2006), Geology, geochronology, and geodynamics of the Khan Bogd alkali granite pluton in southern Mongolia, Geotectonics, 40(6), 450-466.

Kozakov, I. K., A. B. Kotov, V. P. Kovach, and E. B. Salnikova (1997), Crustal growth in the geologic evolution of the Baidrag block, Centra Mongolia: Evidence from Sm-Nd isotopic systematics, Petrology, 5(3), 227-235. 
Kozakov, I. K., E. B. Sal'nikova, E. V. Khain, V. P. Kovach, N. G. Berezhnaya, S. Z. Yakovleva, and Y. V. Plotkina (2002), Early Caledonian crystalline rocks of the Lake Zone in Mongolia: Formation history and tectonic settings as deduced from U-Pb and Sm-Nd datings, Geotectonics, 36, 156-166.

Kozlovsky, A. M., V. V. Yarmolyuk, A. V. Travin, E. B. Sal'nikova, I. V. Anisimova, Y. V. Plotkina, V. M. Savatenkov, A. M. Fedoseenko, and S. Z. Yakovlevac (2012), Stages and regularities in the development of late Paleozoic anorogenic volcanism in the Southern Mongolia Hercynides, Dokl. Earth Sci., 445(1), 811-817.

Kröner, A., J. Lehmann, K. Schulmann, A. Demoux, O. Lexa, D. Tomurhuu, P. Štípská, D. Otgonbator, D. Y. Liu, and M. T. D. Wingate (2010), Lithostratigraphic and geochronological constraints on the evolution of the Central Asian Orogenic Belt in SW Mongolia: Early Paleozoic rifting followed by late Paleozoic accretion, Am. J. Sci., 310, 523-574.

Kuzmichev, A., A. Kröner, E. Hegner, L. Dunyi, and W. Yusheng (2005), The Shishkhid ophiolite, northern Mongolia: A key to the reconstruction of a Neoproterozoic island-arc system in central Asia, Precambrian Res., 138(1-2), 125-150.

Lafehr, T. R. (1991), An exact solution for the gravity curvature (Bullard B) correction, Geophysics, 56(8), 1179-1184.

Lamb, M. A., and G. Badarch (2001), Paleozoic sedimentary basins and volcanic arc systems of southern Mongolia: New geochemical and petrographic constraints, in Paleozoic and Mesozoic Tectonic Evolution of Central Asia: From Continental Assembly to Intracontinental Deformation, edited by M. S. Hendrix and G. A. Davis, Mem. Geol. Soc. Am., 194, 117-149.

Lamb, M. A., A. D. Hanson, S. A. Graham, G. Badarch, and L. E. Webb (1999), Left-lateral sense offset of Upper Proterozoic to Paleozoic features across the Gobi Onon, Tost, and Zuunbayan faults in southern Mongolia and implications for other central Asian faults, Earth Planet. Sci. Lett., 173, 183-194.

Lehmann, J., K. Schulmann, O. Lexa, M. Corsini, A. Kröner, P. Štípská, D. Tomurhuu, and D. Otgonbator (2010), Structural constraints on the evolution of the Central Asian Orogenic Belt in SW Mongolia, Am. J. Sci., 310, 575-628.

Meng, Q.-R. (2003), What drove late Mesozoic extension of the northern China-Mongolia tract?, Tectonophysics, 369(3-4), 155-174.

Monger, J. W. H., R. A. Price, and D. J. Tempelmankluit (1982), Tectonic accretion and the origin of the 2 major metamorphic and plutonic belts in the Canadian Cordillera, Geology, 10(2), 70-75.

Mordvinova, V. V., and A. A. Artemyev (2010), The three-dimensional shear velocity structure of lithosphere in the southern Baikal rift system and its surroundings, Russ. Geol. Geophys., 51(6), 694-707.

Mordvinova, V. V., A. Deschamps, T. Dugarmaa, J. Deverchére, M. Ulziibat, V. A. Sankov, A. A. Artemyev, and J. Perrot (2007), Velocity structure of the lithosphere on the 2003 Mongolian-Baikal transect from SV waves, IzV., Phys. Solid Earth, 43(2), 119-129.

Nabighian, M., M. Ander, V. Grauch, R. Hansen, T. LaFehr, Y. Li, W. Pearson, J. Peirce, J. Phillips, and M. Ruder (2005), Historical development of the gravity method in exploration, Geophysics, 70(6), 63ND-89ND.

Nagy, D. (1966), The prism method for terrain corrections using digital computers, Pure Appl. Geophys., 63(1), 31-39.

Nikishin, A. M., S. Cloetingh, L. I. Lobkovsky, E. B. Burov, and A. C. Lankreijer (1993), Continental lithosphere folding in Central Asia (part I): Constraints from geological observations, Tectonophysics, 226(1-4), 59-72.

Parfenov, L. M., L. I. Popeko, and O. Tomurtogoo (2001), Problems of tectonics of the Mongol-Okhotsk orogenic belt, Geol. Pacific Ocean, 16(5), 797-830.

Parfenov, L. M., A. I. Khanchuk, G. Badarch, R. J. Miller, V. V. Naumova, W. J. Nokleberg, M. Ogasawara, A. V. Prokopiev, and H. Yan (2003), Preliminary northeast Asia geodynamics map, U.S. Geol. Surv. Open File Rep., 03-205.

Pavlis, N. K., S. A. Holmes, S. C. Kenyon, and J. K. Factor (2012), The development and evaluation of the Earth Gravitational Model 2008 (EGM2008), J. Geophys. Res., 117, B04406, doi:10.1029/2011JB008916.

Petit, C., J. Déverchère, E. Calais, V. San'kov, and D. Fairhead (2002), Deep structure and mechanical behavior of the lithosphere in the Hangai-Hövsgöl region, Mongolia: New constraints from gravity modeling, Earth Planet. Sci. Lett., 197(3-4), $133-149$.

Phillips, J. D. (2001), Designing matched bandpass and azimuthal filters for the separation of potential-field anomalies by source region and source type, paper presented at Australian Society of Exploration Geophysicists, 15th Geophysical Conference and Exhibition, Brisbane, Australia.

Qu, J. F., W. J. Xiao, B. F. Windley, C. M. Han, Q. G. Mao, S. J. Ao, and J. E. Zhang (2011), Ordovician eclogites from the Chinese Beishan: Implications for the tectonic evolution of the southern Altaids, J. Metamorph. Geol., 29(8), 803-820.

Ren, J., K. Tamaki, S. Li, and Z. Junxia (2002), Late Mesozoic and Cenozoic rifting and its dynamic setting in Eastern China and adjacent areas, Tectonophysics, 344(3-4), 175-205.

Ruzhentsev, S. V. (2001), The Variscan belt of south Mongolia and Dzungaria, in Tectonics, Magmatism, and Metallogeny of Mongolia, edited by A. B. Dergunov, pp. 61-94, Routledge, London, U. K.

Ruzhentsev, S. V., and I. I. Pospelov (1992), The south Mongolian Variscan fold system, Geotectonics, 26, 383-395.

Ruzhentsev, S. V., G. Badarch, and T. A. Voznesenskaya (1985), Tectonics of the Trans-Altai zone of Mongolia (Gurvansaykhan and Dzolen ranges), Geotectonics, 19, 276-284.

Schulmann, K., and S. Paterson (2011), Geodynamics: Asian continental growth, Nat. Geosci., 4(12), 827-829.

Şengör, A. M. C., and J. F. Dewey (1990), Terranology: Vice or virtue?, Philos. Trans. R. Soc., A, 331(1620), 457-477.

Şengör, A. M. C., and B. A. Natal'in (1996), Palaeotectonics of Asia: Fragments of a synthesis, in The Tectonic Evolution of Asia, edited by A. Yin and T. M. Harrison, pp. 486-640, Cambridge Univ. Press, Cambridge, U. K.

Şengör, A. M. C., B. A. Natal'in, and V. S. Burtman (1993), Evolution of the Altaid tectonic collage and Paleozoic crustal growth in Eurasia, Nature, 364, 299-307.

Simpson, R. W., R. C. Jachens, R. J. Blakely, and R. W. Saltus (1986), A new isostatic residual gravity map of the conterminous United States with a discussion on the significance of isostatic residual anomalies, J. Geophys. Res., 91, 8348-8372, doi:10.1029/JB091iB08p08348.

Spector, A., and F. S. Grant (1970), Statistical models for interpreting magnetic data, Geophysics, 35(2), $293-302$.

Štípská, P., K. Schulmann, J. Lehmann, M. Corsini, O. Lexa, and D. Tomurhuu (2010), Early Cambrian eclogites in SW Mongolia: Evidence that the Palaeo-Asian Ocean suture extends further east than expected, J. Metamorph. Geol., 28(9), 915-933.

Syberg, F. J. R. (1972), A fourier method for the regional-residual problem of potential fields, Geophys. Prospect., 20(1), 47-75.

Teng, J., Z. Zhang, X. Zhang, C. Wang, R. Gao, B. Yang, Y. Qiao, and Y. Deng (2013), Investigation of the Moho discontinuity beneath the Chinese mainland using deep seismic sounding profiles, Tectonophysics, 609(0), 202-216.

Volkova, N. I., and E. V. Sklyarov (2007), High-pressure complexes of Central Asian Fold Belt: Geologic setting, geochemistry, and geodynamic implications, Russ. Geol. Geophys., 48(1), 83-90.

Webb, L. E., and C. L. Johnson (2006), Tertiary strike-slip faulting in southeastern Mongolia and implications for Asian tectonics, Earth Planet. Sci. Lett., 241(1-2), 323-335.

Wellman, P. (1988), Development of the Australian Proterozoic crust as inferred from gravity and magnetic anomalies, Precambrian Res., 40-1, 89-100. 
Windley, B. F., D. Alexeiev, W. Xiao, A. Kröner, and G. Badarch (2007), Tectonic models for accretion of the Central Asian Orogenic Belt, J. Geol. Soc., 164(1), 31-47.

Xiao, W., B. F. Windley, G. Badarch, S. Sun, J. Li, K. Qin, and Z. Wang (2004), Paleozoic accretionary and convergent tectonics of the southern Altaids: Implications for the growth of Central Asia, J. Geol. Soc., 161(3), 339.

Xiao, W., C. Han, C. Yuan, M. Sun, S. Lin, H. Chen, Z. Li, J. Li, and S. Sun (2008), Middle Cambrian to Permian subduction-related accretionary orogenesis of Northern Xinjiang, NW China: Implications for the tectonic evolution of central Asia, J. Asian Earth Sci., 32(2-4), 102-117. Xiao, W. J., et al. (2009), Paleozoic multiple subduction-accretion processes of the southern Altaids, Am. J. Sci., 309(3), 221-270.

Yarmolyuk, V. V., and V. I. Tikhonov (1982), Late Paleozoic magmatism and fault tectonics in the Trans-AKtai Gobi, Mongolia, Geotectonics, 16(2), 123-130.

Yarmolyuk, V. V., V. I. Kovalenko, A. M. Kozlovsky, V. P. Kovach, E. B. Sal'Nikova, D. V. Kovalenko, A. B. Kotov, E. A. Kudryashova, V. I. Lebedev, and G. Eenzhin (2008), Crust-building processes in the Hercynides of the Central Asian Foldbelt, Petrology, 16(7), 679-709.

Yarmolyuk, V. V., M. I. Kuzmin, and A. M. Kozlovsky (2013), Late paleozoic-Early Mesozoic within-plate magmatism in North Asia: Traps, rifts, giant batholiths, and the geodynamics of their origin, Petrology, 21(2), 101-126.

Zaitsev, N. S., B. Luwsandansan, N. A. Marinov, V. V. Menner, T. G. Pavlova, A. V. Peive, P. P. Timofeev, O. Tomurtogoo, and A. L. Yanshin (1970), Stratigraphy and Tectonics of the Mongolian Peoples Republic, Trans. Joint Soviet-Mongolian Sci. Res. Geol. Exped., pp. 148, Nauka Press, Moscow.

Zhang, S., et al. (2014), Crustal structures revealed from a deep seismic reflection profile across the Solonker suture zone of the Central Asian Orogenic Belt, northern China: An integrated interpretation, Tectonophysics, 612-613(0), 26-39.

Zonenshain, L. P. (1973), The evolution of Central Asiatic geosynclines through sea-floor spreading, Tectonophysics, 19(3), $213-232$.

Zonenshain, L. P., O. D. Suyetenko, L. Jamyandamba, and G. Eengin (1975), Structure and the axial part of South Mongolian eugeosyncline in the Dzolen Range, Geotectonics, 4, 28-44.

Zorin, Y. A. (1999), Geodynamics of the western part of the Mongolia-Okhotsk collisional belt, Trans-Baikal region (Russia) and Mongolia, Tectonophysics, 306(1), 33.

Zorin, Y. A., et al. (1993), The South Siberia-Central Mongolia transect, Tectonophysics, 225(4), 361. 